\title{
わが国における化学装置・化学機械の発展
}

化学工学協会ははしめ化学機械協会として発足した。25 年の歳月におけるこの名称の変化は, そのま ま日本の化学機械工業の展開の過程を端的に物語っている。戦前の外国機器模做時代から幾多の曲折を たどって，上らやく落付きと自信をとりるどし，将来への羅進に対する態智ができあがりつつあるのが 現状であろう。ここに表題のよ 5 な特集を計画し, 多数の方々のこ執筆を煩わせて, 記念号の一部を飾 ることができたことを執筆者各位に対して厚くお礼申し上げる。たたし，執筆者こ多仙のため，すへて の分野を網羅できず，かつ記述の形式にやや統一を欠いたうらみがあるが，これはすへて委員会に責任 がある。ここに会員諸子のこ寬㤎を乞う次第である。

(林 健 樹*)

\section{化学 機械工業}

展

望**

藤 山 覚一郎***

日本の化学機械工業の発展過程をたどり，その性格, 今後の方向をさぐるためには，ひとつにはその顧客であ る化学工業のわが国に打ける特徵的発達の歴史がまず 展望されねばならぬだろう。なせならば，日本において は，化学機械工業はそれ自体として明瞭な成立基盤をこ く最近までは確立していなかったのであり, 少数の例外 をのぞけば, いわば化学工業および一般機械工業両者の 便宜的な結合形態として，存在していたともいえるから である。

\section{1. 日本の化学工業の発展}

いまかんたんに日本の化学工業史を主として技術中心 に考えてみるとつぎの 4 期にわけられるであろう。

（1）大正初年よりはじまる勃興期 近代的な意味 での化学工業が本格的に成立しはじめたのは明治末期・ 大正初年ごろからであろう。それまでの官営企業的な硫 酸や火薬の製造は，生産形態そのすのす，きわめて前近 代的であった。しかし，大正期に入ると，近代的化学工

* 千代田化工建骰（株）

** 昭和 36 年 7 月 12 日受理

*** 日東ニニカー(株)
業のひとつの特質と考えられる，「単一品生産から複合 的多角的生産構造への移行」が，あるいは三井系企莱仡 打ける硫酸-染料工業,あるいはンーダ・塩素工業の例の ことく意識的に開始されたのである。また日本の化学工 業のひとつの特徵として,アンモニアー硫安系肥料工業が きわめて大きなウエイトを占めていることが資本的，技 術的両面より指摘されるが，この工業す大正 10 年鈴木 商店によるクロード法導入 (颜島工場), 大正 13 年のカ ザーレ法導入（延岡）飞始まっているのである。この時 期以来，それまでの企業形態から一歩進んで，装置工業 の特性の把握, 多角性, プロセス全体の有機的関連性な どについてのある程度の認識, にもとついた企業化が行 なわれてきたのである。

しかし，各プロセスの具体的な技術・装置は，ほとん どが外国よりの一括輸入に依存していたのであり，たと えばアンモニア工業における各国技術の導入は，よくい われるように，展示会的なバラェテイに富んでいたので ある。したがって装置提供者としての化学機械工業はほ とんどなんの役割す果していなかったといえよう。

（2）昭和 6,7 年頃より第 2 次大戦前までの時期 この時期には，各社における技術習熱の度合が進み，独 自の技術体系を産み出す機運が生じたことが指摘されよ う。すなわち, 触媒研究, 工程研究などにて国産技術開 発の萠芽があらわれてきた。同時に，この時期に执いて 注目すべき点は，各個別私企業以外の，いわゆる国策的 あるいは軍時的要因にもとつく国産技術の発展・蓄積が 
進行したことである。

そのおるなンースは，陸海軍，とくに海軍関係におけ る石油精製を中心とするプロセス技術，（海軍航空廠に おける軽油分解，水添のプロセス，然料廠に拉けるイソ オクタン合成など））満州・朝鮮に拈ける一連の重化学 工業（撫順での石炭液化装眉など）のこころみ，おるい は工業試験所に怙ける研究などがあげられる。これらの ろちで本格的に完成されたものの数は多いとはい充ない が，従来の個別反応研究と違った総合プロセス技術の開 発という点で記憶さるべき業績がいくつか残されてい る。しかし，このよ5な国産技術蓄積へのモメントす， けっきょくは第 2 次大戦により中断されてしまったので ある。ただし，注目すべきことは，これらの軍関係ある いは，満州・朝鮮で蓄積された人的資源が，現在の化学 機械工業内に大きく流入して生かされているという事害 である。

いずれにせよ，これまでの段階では，化学工場建設に 当っては, 化学会社自体が工務スタッフを大量にかか 之, 化学機械メーカーは化学会社よりの個別単能機器の 発注を受けて，単に仕様どおりの製作にあたるという役 割しか演じなかったのである。

（3）つぎの時期は, 終戦直後よりのいわば再建期で ある。この期には, 自力による装置, 機械の復旧・整備 が各企業にとって何よりもとりくまなければならない命 題であった。特にアンモニア工業は，食糧政策との関連 において，国家資金による育成方針のるとに強力な復興 をなしとけ゚た。そしてこれは自力により（つまり外国 での進歩した技術とは無緑に）行なわれたことに注意せ ねばならない。いわば「復興」は単に「復元」であり， その意味においての自力技術依存にすぎなかったわけて あり，当然世界的水準との技術的ラッグはなんら縮少さ れなかったのである。

（4）したがって，その次のいわゆる「技術革新期」 （たとえば硫安工業においては昭和 26 年の肥料統制撤 廃期以来）に括いては，合理化，近代化はほとんどすべ て外国技術の導入によって行なわれ，最近にまでいたっ ている訳である。

たとえば，つぎの表 1 をみれば，化学工業は他の工業 兼種に比較して技術導入度が高く，また業界内にあるる のの実感としても，各社きそってのプロセス・ノウハウ の輸入は他業種にくらべてあまりに顕著である。

このような新プロセス導入にともなって, 操業の形態 は, 従来のハッチ式から, 自動化, 連続化, オートメー ション化へと完全に転換しつつあり，生産体系も石油化 学コンビナートに代表されるような複雑なシステムとな ってきた。しかる，装置自体が重合反応のごとき微妙な
表 1

外資法による技術援助契約件数

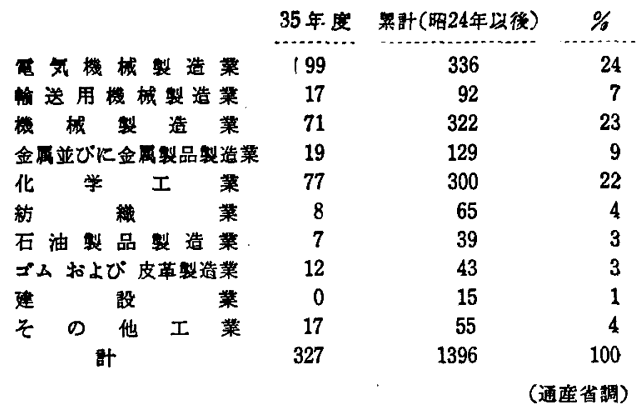

コントロールを必要とするものが多くなり，また，それ ら装盾の改良・更新のテンポはきわめて早くなってき た。このような状況になると，とうてい従来のことき化 学メ一カー自体のもつ工務スタッフでは能力的にカバー できなくなり，また強いてカバーしようとすれば，常時 龙大なスタッフを抱えておかなければならない。これは 化学メ一カー自体としては当然たえきれない負担であ る。したがって，欧米の先進諸国でみられるような操業 と建設の分離, 総合プラントメーカーの必要性が化学工 業のがわから㥶され出したわけである。

\section{2. 化学機械工業の展開}

前節で, 化学機械工業の顧客である化学工業の過去と 現状を，簡単に鳥㒈してみた。そこでここような化学 工業の発展段階にそくして, 化学機械工業の過去は, 現 在にいかに関連してきたかをつぎに見ていくことにしよ 5 。

ところでこれまで化学機械工業といったことばをわ れわれは使ってきたが，いったいこのことばは具体的に どのような業種をさすのであろらか。

いま，一応の目安として，通産省の機械統計をみてみ长 ると，そこにはつぎの表 2 のような分類によって，「化 学機械」なるジャンルが存在している。たしかにここに 分類されている機器は，いずれるなんらかの形において 化学反応に関与する単能機器類である。また, ほぼこの 分類に依拠した資料によれば，わが国のこれら化学機械 の年度別生産実績の5ごきは表 3 のようになっている。

たとえば，昭和 $4,5,6$ 年の停滞期をすぎて昭和 8 年 には 3 万トン, 2,900 万円の総生産量をしぬし, 以後上 舁の一途をたどり，昭和 14 年には生産量は 10 万トン, 1 億 3 千余万円のピークに達している。以後大戦中の状 沉は資料がまとめられていないが，終戦以来峏調にの びて括り，ことに 35 年は設備投資拡大の波にのり，生 産金額 800 億を記録している。 
表 2 化学機械分類

(通産省梳叶に上る)
（大分類）

A.

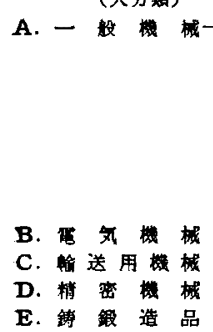

（中分短）

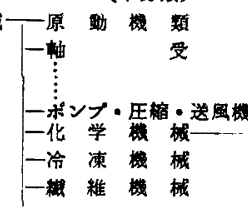

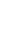

椷

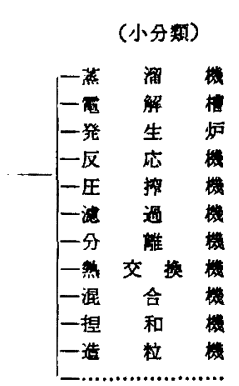

表 3 化学機械年度別生産実縝

\begin{tabular}{|c|c|c|c|c|c|}
\hline 年 & 度 & 臭是(トン) & 金額 (千角) & 工塨 & 征莱員数 \\
\hline \multirow[t]{2}{*}{ 昭和 } & 5 & 11,670 & 5,240 & 126 & 2,804 \\
\hline & 8 & 30,309 & 20,336 & & \\
\hline & 10 & 43,166 & 31,339 & 272 & 8,667 \\
\hline & 12 & 62,479 & 58,543 & & \\
\hline & 14 & 104,747 & 134,914 & & \\
\hline & 16 & 97,458 & 203,297 & & \\
\hline & 18 & N.A. & N.A. & & \\
\hline & 20 & 73,635 & 279,670 & 303 & \\
\hline & 22 & 52,107 & $1,513,465$ & & \\
\hline & 24 & 64,528 & $5,425,222$ & & \\
\hline & 26 & 99,691 & $17,219,406$ & & \\
\hline & 27 & 89,200 & $20,419,519$ & 431 & \\
\hline & 28 & 89,200 & $17,500,000$ & & \\
\hline & 29 & 94,000 & $19,720,000$ & & \\
\hline & 30 & 109,600 & $25,106,000$ & & \\
\hline & 31 & 148,500 & $47,500,000$ & 303 & 110,000 \\
\hline & 32 & 117,766 & $41,665,649$ & & \\
\hline & 33 & 113,512 & $38,863,372$ & & \\
\hline & 34 & 152,425 & $45,084,935$ & & \\
\hline & 35 & 233,757 & $80,051,091$ & 230 & \\
\hline
\end{tabular}

(産乗機械坫会调查)

また,この表の右にかかげた工場数と従業員数は, 昭 和 5 年に 126 工場 2,800 人が昭和 15 年には工場数 676 従業員 33,000 人とふくれあがったのであり, 戦後は昭和 31 年現在工場数 300 従業員数 11 万人を雍する業種とな っているのである。

そころで，化学機械工業の実体を知るには，むしろこ の工場数の統計が大きな手がかりとなるのである。第 1 にいえるのは，化学機械とい5統計ジャンルが確立した のが昭和 5 年であることからわかるとおり, 先の化学工 業の発展の第 1 段階にはまだ化学機械工業とい5観念は まったくなかったといえよう。この時期では，化学工業 のプロセス自体も，ほとんと゚ハッチ式な個別工程であり ，そこで用いられる装置も，主として容器と運搬機とい う単純な性格の結合にすぎなかったのである。

つぎの第 2 期（昭和 6,7 年以降）の化学工業段階にい たって, はじめて化学機械の専門性が明らかになり, 統

計的な分類も確立した。容器は反応機, 発生炉, 蒸溜機, 混合機などに分化してゆく。あらゆる産業が経験するご とく，初期の未分化状態からの脱却が括こり，機能の専 門化，細分化が進行したのである。

戦後の復興期は, 戦前の最盛期への復元として把握さ れるが，その後の第 4 期では，化学機械工業ははじめて 大きな革新の時機婂入ったのである。すなわち, 従来の 単能・細分機器は，らたたび総合的なプロセス技術の見 地から，総括的に整理されてゆくのである。

つまり, 従来の単能機器とい5すのは，それ自体に拉 いてはたん機器であるのにとどまり，それが特定の生 産システムの中に投下され，他の要素と組み合わされる そきル、はじめて特殊的機能を発揮するのであった。（た とえば，ボイラーはあるときは発電用ボイラーであり， また船舶用ボイラーであり，かつまたプロセス蒸気用ボ イラーともなるのである。)

これに対して，新らしい動きは，化学プロセスを全体 としてまずつかみ，そのプロセス構造をまずとらえてか ら，部分機器の特性を全体の構造の中に適合させていく やり方である。既存単能機器を積木細工のごとく各機械 メーカーからよせ集めして，全プラントを組み立てるの ではなく，全プラントの有機的結合をはじめにデザイン して，サブシステムを割り出していくといら立場がそれ である。

\section{3. 化学工学の進歩}

ここで，化学機械工業の第 3 の柱である化学工学の発 展が，上のような変移の大きな支柱となっていることも 注目しなければなら收である。

化学機械工業の基礎的学問としての化学工学が，独立 した工学領域として認識され始めたのは，20世紀初頭で ある。それまではさささの日本の化学工業の第 1 期がまっ たくの摇籃時代であったと同様な意味での，学としての 発生期を経由していたのであった。1902 年に G. Davis が彼の著書の標題に “A Handbook of Chemical Engineering”を採用したのか，怙そらく化学工学の体系的 確立の第 1 歩であろう。以後 1915 年に M.I.T. にて, A.D. Little が Unit Operation の概念を提出して, 現 在までの化学工学の実質的基盤をうちたて, さらに1922 年に American Institute of Chemical Engineers が設 立され，Chemical Engineer の職業的地位が明瞭になっ たわけである。

ところで, この比較的若い工学の発達を概観すれば,

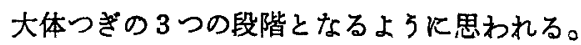

イ. 工業熱力学と化学平衡論の結びつきによる物質収 支, 熱収支に基つく装置設計論 
表 4 化学機誠生産階層別分析表（昭和 32 年 1 月現在）

（通菜機械協会略查）

\begin{tabular}{|c|c|c|c|c|c|c|c|c|c|c|c|}
\hline 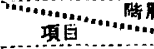 & 別 & A & $\mathbf{B}$ & C & D & $E$ & $F$ & $\mathbf{G}$ & $\mathbf{H}$ & I & 部 \\
\hline 場 & 数 & $\begin{array}{r}18 \\
(7.64)\end{array}$ & $\begin{array}{r}16 \\
(6.78)\end{array}$ & $\begin{array}{r}10 \\
(4.22)\end{array}$ & $(5.94)^{14}$ & (14.85) & $\begin{array}{r}59 \\
(25.00)\end{array}$ & $\begin{array}{r}55 \\
(23.30)\end{array}$ & $\begin{array}{r}10 \\
(8.05)\end{array}$ & $\begin{array}{r}10 \\
(4.22)\end{array}$ & $(100.0)^{236}$ \\
\hline 徉畨，心 & 数 & $\begin{array}{r}55,166 \\
(63.21)\end{array}$ & $\begin{array}{r}12,121 \\
(18.34)\end{array}$ & $\begin{array}{r}3,835 \\
(4.45)\end{array}$ & $\begin{array}{r}3,619 \\
(4.15)\end{array}$ & $\begin{array}{r}5,837 \\
(6.69)\end{array}$ & $\begin{array}{r}4,231 \\
(4.86)\end{array}$ & $\begin{array}{r}1,797 \\
(2.08)\end{array}$ & $\begin{array}{r}450 \\
(0.56)\end{array}$ & 147 & 87,203 \\
\hline & 量 & $\begin{array}{r}2,142 \\
(16.25)\end{array}$ & $\begin{array}{r}4,564 \\
(34.65)\end{array}$ & $\begin{array}{r}1,255 \\
(9.55)\end{array}$ & $\begin{array}{r}1,369 \\
(10.45)\end{array}$ & $\begin{array}{r}1,408 \\
(10.65)\end{array}$ & $\begin{array}{r}1,580 \\
(12.20)\end{array}$ & $\begin{array}{r}711 \\
(5.45)\end{array}$ & $\begin{array}{r}100 \\
(0.80)\end{array}$ & $\begin{array}{r}27 \\
(0.03)\end{array}$ & $\begin{array}{r}13,156 \\
(100.0)\end{array}$ \\
\hline 座 & 額 & $\begin{array}{l}646,309 \\
(17.72)\end{array}$ & $\begin{array}{r}1098,758 \\
(30.10)\end{array}$ & $\begin{array}{l}438,146 \\
(12.00)\end{array}$ & $\begin{array}{r}363,794 \\
(9.95)\end{array}$ & $\begin{array}{l}463,802 \\
(12.76)\end{array}$ & $\begin{array}{l}368,911 \\
(10.14)\end{array}$ & $\begin{array}{r}225,048 \\
(6.16)\end{array}$ & $\begin{array}{l}32,818 \\
(0.91)\end{array}$ & $\begin{array}{r}6,244 \\
(0.26)\end{array}$ & $\begin{array}{r}3,646,830 \\
(100.0)\end{array}$ \\
\hline
\end{tabular}

階屏别 A; 1000 人以上, B; 500 999人, C; 300 499人, D: 200 299人, E; $100 \sim 199$ 人, F;50 99人, G; 30 49人, H; $20 \sim 29 人$ I; 19 人 以下

ロ. 反応速度論的取报いを装置設計の面にとり入れて いく発展

八. 制御・システム理論を単位操作にかえていく方向

第 1 の立場は今は古典的々なった Walker, Lewis， McAdams \& Gilliland の名著 “Principles of Chemical Engineering”によって代表されており，化学工 学の中にとり入れていこ5とい5第 2 の方向への拡張 が, Eucken やHougen-Watson の本で意識的になされ たのである。

つまり初・中期までの化学工学(第 2 次大戦前)は, 二 ニット・オペレーションの機械的組み合わせのみをその 主題としてきた。工程は個々の部分機能に分断され，汇 過, 流体輸送, 伝熱, 蒸留といった単独機能についての 工学がいわばバラバラに追求されたのである。

このような機械的特性により化学工業プロセスをみる 立場は，まさに前記した化学機械工業の旧来のあり方に 符合するすのであろう。しかしニニットプロセス的に反 応（たとえば酸化・ハロゲン化など）を類型化し，反応 プロセス自体の特性をしかも速度論的に解明していくと いら方向は, 単能機械の個別的デザインだけではカバー できない技術を要求しはじめた。さらに，近年の第 3 の 方向への拡張がこれにひきつついて現在進行しているの である。つまり, 従来の化学工学が, 個別装置のデザ インや，熱・物質バランスの「量」的面の考案のみを追 求したのに対し, 全体の装置系の総合的な system performance の「質」を考えてデザイン製作を行ならとい う考え方にすすんできたのである。コントロール・シス テム・エンジニアリング1)といった言葉が化学工学の中 にとり入れられてきたのはかかる動きに対応しているの である。

このような化学プロセスのシステム的把握という化学 工学の発展につれて, 単能機械からシステム物へといっ

1) Johnson, E.F.,Chem. Eng. Progress, 54, 41 (1958)
た動きが化学機械メーカーの中に括こってきたのは当然 そいえるのであろう。

\section{4. 化学機械工業の現況と将来}

さて以上のような背景のすとに発展してきた化学機械 工業界の現状を知るために，ややふるい資料であるが表 4 の業界構成分析をみてみよ5。これでみると，まず工 場数では， 300 人以上の従業員数をるつすのは 44 , 全体 の 18 パーセントで，それ以下の規模の中小企業的工場 は192 工場, 81 パーセント,このなかですとくに 30〜100 人クラスの小企業が, 48 パーセントと半数近くを占めて いる。一方生産量では 300 人以上の工場が数量で 63 パ 一セント, 金額で約 60 パーセントの比重となっている。

そこで，さらにこの大小さまさまの企業の内容をみて

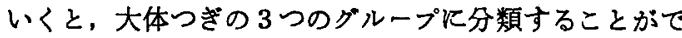
さよう。第1は主として中小メーカー上りなる単能機器 の専門業者である。これらは，機能的にきわめて細分化 された個別装置の製造・修理にのみ従事しているわけで ある。そして，これらの中小メーカーは，それぞれの専 門分野において（たとえば粉砕機，造粒機など）独自の 技術を蓄積し，確固たる技術水準を保存しているところ あ少なくないが，全体としてみれば，下請工場的な性格 をすつるのが多く，近代的プロセスとむすびついたオリ ジナルな技術の発展を期待するには，資本的，市場的に も弱い点を有することは否めないであろう。

第 2 には総合的重機械メーカーが，化学機栰部門を兼 営している形態があげられる。たとえば，石川島重工， 神戸製鋼，久保田鉄工，三井造船などがそれである。こ れらは昭和初期より主部門たる造船, 重機などの生産の 側面的安定策，ないしは蓄積技術の有効活用といったよ ろなモメントより, 漸次化学機械部門䎲進出して来たる のなのである。いわば化学プロセス工業内の機械的要素 そ，一般重機械工業とをたんに要求される機能の面のみ で結合させた形である。したがって，すくなくとも数年 
前までは，そこにはプロセス工業のシステム的把握とい った意識は見られず,化学メーカーの要求にしたがって, 個別機器の性能さえギャランティされればよいといった 立場にあったのである。

いままでの，前とのべたような市場としての化学工業 自体の推移に限っていえば、充分上の 2 業態で化学機械 工業の役割を果してきたのである。

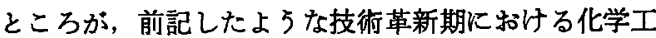
業側でのプロセス近代化, 自動化, 多角化の進行々, 学 問としての化学工学の総合プロセスエンジニアリングヘ の発展にとすなって，第3の型すなわちいわゆるエンジ ニアリング・カンパニー，あるいはプラントメーカーと よばれる性格の企業が生まれることになった。つまり， 反応工程・補助工程の組み合わさった複雑なシステムと しての化学プラント全体をこなせるだけのノウ・ハウの 蓄積をるった技術会社が必要となってきたのである。こ の型の会社では, プロセス開発 (Process Engineering) 設計 (Project Engineering), 調達 (Procurement), 機 器製作 (Manufacturing), 建設 (Construction) のひろ い分野をカパーすることになる。るちろん，実際上は， 業態は一様でなく、アメリカです，プロセスの開発から テスト操業まで一貫して請負う会社よりも，たんにデザ インをおこない，装置機器製作は外注し，施工をさらに 担当するといった会社が多い2)。この第 3 の型の会社， なわち全プラントの設計建設能力を多かれ少なかれ有し ている会社は現在は千代田化工，日本揮発油両社に上。 て代表されるが，近年石川島フォスターホイーラー社， 飯野テイアーズ社，あるいはやや特殊な領域のみに携っ ているすのとして日本理化工業, 日本真空技術, 日本鍊 水などの各社があらわれてきている。さらに最近注目す べき動きは，主として第2のグループの大企業（とくに 造船メーカー，たとえば日立造船，三井造船，川崎重工， 藤永田造船など）が，第 3 グループの型態に進出をはじ めたことである。現在のところこれれら各社は，子会社 の形でエンジニアリング・カンパニーを設立して，ホー ルプラント設計能力を蓄積しつつあり，各社の資本的ま たは基礎技術的実力からみて，近い将来大きなウエイト を化学機械工業内で占めてくることが充分予想されるの である。さらに，化学会社側においても，さきにのべた ような操業と設計・工作の分離がすすんだ形として，た とえば東洋高压の工務部門による東洋エンジニアリング 社の設立にみられることき，プラント部門進出の5ごき む出てきているのである。

このようにみるとき，今後の化学機械業界は従来の単 能機械メ一カーの専門分野的発展ととすに; 大企業の進

2）楼口隆吉，化学工学 No.3 (1959)
出, プロセスエンジニアリング的機能への発展といった 構造的変貌をしぬしていくのではないかと思われる。そ して，われわれはそのモメントとして，化学工業自体の 生産体系の近代化（多角化，自動化，計装化，および操 業と建設の分業化)，および化学工業自体のシステム工学 的進歩を考えたわけである。

今後このような動きが進むにつれて、われわれが何よ りも考えなければならない点は，化学工業と化学機械工 業との緊密な連蘩である。前にもいったような化学工業 自体のプロセスの進歩改良のテンポはきわ的て早い。装 置の陳腐化あるいは既設装置の改造を化学メーカーのみ でこなしえなくなったことは明らかである。そこにこそ 化学機械工業の新しい役割がうまれるのであり，その役 割の発展のためには，なによりるユーザーである化学工 業会社とプラントメーカーとの技術的交流が必要条件で ある。従来のわが国の化学会社が外国技術を導入すると きは，その過程はまったく閉鎖的であり，仕様にあとつ いて国産機械メーカーは部分機械の発注を受け，メーカ 一自身どのように使用されるかす不明のままに製作され るのが多かった。秋入後の装置のパーフォマンスなどに ついての情報す，ほとんど担当した機械メーカーにフィ ードパックされることがないのである。このような状態 からは，国内機器メーカーに進歩した技術蓄積をの气を のはむりであり，これが再び化学会社側の外国技術依存 を強めさせるという循環状沉をすたらしているのであ る。

このよ5な悪循環を打破して, 化学工業と化学機械工 業の緊密な技術交流のもとに，国内技術が蓄積され，そ の水準が高まれば，日本の化学機械工業は，その年々発 展する国内市場を確保できるばかりでなく，豊富低廉な 人的資源の強味を最大限に発揮して国際市場に進出でき ると充分考觉られるのである。

最近業界扣よび関係官庁の間で立案されている化学機 械工業振興基本計画でも，35 年輸出額 18 億円に対し, 昭和 38 年度目標を 70 億円に定めている(表 5 参照)。国 内重化学工業の発展の基盤として，あるい後進諸国で の工業化の進展に貢献するるのとして, 化学機械工業の 質的発展が大い期待されるゆえんである。

表 5 化学機械輸出入実績および計画

\begin{tabular}{|c|c|c|c|c|c|c|}
\hline & 昭32年 & 33 & 34 & 35 & $\begin{array}{c}36 \\
(\text { 目標) }\end{array}$ & $\begin{array}{c}37 \\
\text { (目標) }\end{array}$ \\
\hline $\begin{array}{r}\text { 犃出(トン数) } \\
\text { (百万) }\end{array}$ & $\begin{array}{r}2,514 \\
771\end{array}$ & $\begin{array}{r}1,948 \\
720\end{array}$ & $\begin{array}{l}2,871 \\
1,179\end{array}$ & $\begin{array}{l}4,902 \\
1,852\end{array}$ & 2,890 & 4,500 \\
\hline 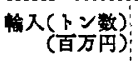 & $\begin{array}{l}2,911 \\
3,409\end{array}$ & $\begin{array}{l}1,252 \\
1,414\end{array}$ & $\begin{array}{l}2,625 \\
2,680\end{array}$ & $\begin{array}{l}2,024 \\
2,991\end{array}$ & & \\
\hline
\end{tabular}


蒸発 装

\section{照井 鐘 二**}

最近までの蒸発装置の発達の概略をまとめたのが表一 である。蔒発缶の生産は，戦後の工業復興ととすに年を 追って增加し, 昭和 27 年, 1952 年頃, 101 台程度の製 作であったが，表 2 に示すよ5に近年にいたり，飛藋的 に延びてきている。

各種の工業において外国との技術提携が盛に行われて いるが，蒸発装置に関してはあまりなく，日立造船とア メリカの A.H.Lundberg Inc. とが 2 種の技術提搭を行 なっているのと，昭和33年, 34 年, 35 年にわたり「クラ フトパルフ黒液涱鏥用真空蒸発缶の設計に関する技術」 の提拃があったくらいである。

最近の特許をつ変った型式の蒸発装置としては,つ ぎの 2,3 のすのがある。

東洋化工機の蒸発缺は, 外部加熱型のすので, 蒸発室 1 個に対し，加熱部を 2 個持っており，ダウンテーキを 2 重管として第 1 缶の供給液は，ダウンテーキの外側を 通って循環しており, 第 2 缶目の従来の外部加熱型て濃 狳された液は，さらにポンプにて第 1 缶へ民り，今度 は第 1 缶のダウンテーキの内側を通って循環し濃縮され る。これは濃縮につれ，粘性を增大寸るよ5な溶液に適 するようである。

大同化学のすのは，低温 2 重効用で紡系溶液の濃縮に 用いられ，第 1 缶の発生ベーパーを温アルカリ液で洗滌 し硫化水素を除去するベーパー清浄装置を採用している。
三菱造船では，パルプ廃液および，化学用各種溶液な どのスケール付着の心配のあるすのについて研究し，逆 循環式蒸発缺を開発した。これはケスナー型のことき垂 直長管式で中央にダウンテーキを持ち，プロペラによっ て逆循環方式を採用したすのでスケールの付着を僅少に し，液の循環速度す高いので熱効率もよいよ5である。 またこの外飞る，予熱器を内蔵した㹂形長管式の蒸発缶 るある。

また計測関係の計器も昭和 30 年頃より急速に発展し, 32 年頃より徐々に単缶, 多重効用缶の運転に使用され始 め, 液面制御, 加熱蒸気, 供給量, 製品量の流量制御, 製品の濃度を検出して抜出量を制御したり，奻用缶の最 終缶圧力の自動制御など各制御方式が注とんど完成し， 実用化されている。

最近の国外飞おける新しい型式のものとして，落下膜 式の強制循環型のすのが, アルミナソーダ液濃縮に使用 され，伝熱係数の非常な增大を報告している。

またフラッシュ型の蒸発法として，海水からの蒸溜水 を作るのに圧力差を持った蒸発室のみの多重効用で，海 水の顕熱による自己蒸発により濃縮される方式で多量の 蒸溜水を製造している。さらに，回転円皻，回転抒取刃 蒸発缶など加熱面を回転させる方法や，塩水など対し ては、冷凍濃縮法、イオン交換膜法など大規模なモデル プラントを用いて実験が行なわれつつある。

表 2 蒸発缶生産実積

\begin{tabular}{ccccc} 
年 $\quad$ 次 & 制作台数 & Ton 数 & 金類 (千円) \\
\hline 1957 & 273 & 1,737 & $1,011,906$ \\
1958 & 163 & 2,494 & $1,274,207$ \\
1959 & 361 & 3,507 & $1,675,755$ \\
196 & 0 & 579 & 4,985 & $2,089,467$
\end{tabular}

\footnotetext{
- 昭和 36 年 8 月9日受理 **月岛機械（株）
}

表 1 蒸発装置型式および使用産業年次

\begin{tabular}{|c|c|}
\hline 次 & 状 \\
\hline $\begin{array}{l}\text { 1860 1910 } \\
\text { 明治年間 }\end{array}$ & 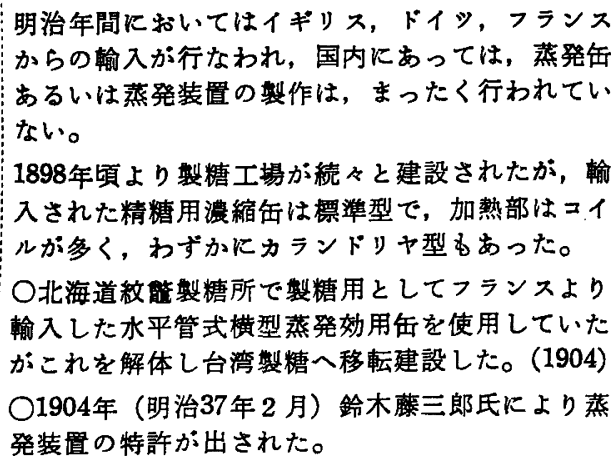 \\
\hline
\end{tabular}

国外 の 状況

○Zaremba式水平管型蒸発器が作り出された。こ れは加熱部が水平管のパイプからなる㹂型のもの である。(1870)

○Yaryan 式が考案された。水平管 型が改 良さ れ，泡立ち易い液すなわちりーダパルプ液，膠， ゼラチンなどに成功した。(1885)

○Yaryan 式を改良した水平式蒸発器にポンプを 付け強制循環を行なわせたすのが作り出され，蒸 溜水の製造に広く使用された。(1890)

○アメリカでは，加熱管を傾斜させた Buflovac 式の傾斜管型蒸発器が作り出され，泡の这ち易い 液体を処理するのに最も効力を発揮した。(1890) 
（1）重嘼式無気蒸発装置

(2) 蒸発装嘈

この特訴が蒸発装置としての日本で最初のすので あろ5。

（1）は蒸発缶を緃型に積重ね，各缶の底部にコイ ル型の加熱管を装入し, 液は最上部の環状管より 散布し順次自動的に下降しながら濃縮され, 最底 部より拉き出す。各缶の蒸気は, 中央を通り最上 部から午外へ出される。液からの蒸発が迅速完全 なよ5に迴転する配液盤をすち，伝熱面上に平均 に散布させる。

（2）は（1）の改良型でコイル型の加熱管を数段に おき，配液盤を液の射入力により自動的に廻転さ せ, 液の平均な下段への散布と蒸発作用を完全に 行なわせるよう考案されたものである。

これに似た綐型の重畳式のるのでPecquer 式多重 奻用蒸発器が考案され，1830年パリにおいて初め て真空の効用缶として用いることができるよ5に なった。

1911～1940 1915年第 1 次世界大戦がおこり外国からの輸入が 大正から 戦前まで 絶え、ここに始めて国産による蒸発装管が製作さ れるにいたった。

○帝国製糖へ国産の初めての瀑縮結晶缶, コイル 型が製作された（1915）

○製糖工場が続々と建設され瀑縮結晶缶に引き続 き $1800 \phi \mathrm{m} / \mathrm{m}$ の 4 重効用缶 1 式す製作されるに いたった。(1917)

○日本染料へす2 重効用缶が納入された。(1917) ○製薬会社へ銅製のカランドリヤ型蒸発缶が納入 された。(1920)

○味の素, 製塩用としてもカランドリヤ型の真空 蒸発装膡， $2 ， 3 ， 4$ 重効用缶が次々に製作され 始めた。(1920)

○製塩用としてST 式，カナワ式を経て真空効用 蒸発装圈が確立し，ついで三田尻公社試験所で加 圧式の標準型 2 重効用缶が建設せられた。(1930) ○人縝レーヨン用としてケスナー型,フィルム式 の酸蒸発装置が作り出され, 以前はカランドリヤ 型ばかりであった苲発装固す新しい型の国産が始 めて作られるよ5になった。(1932)

○当時ほとんど自然循環式であったが，昭和11年 工業大博䜿会が開かれ，月島機械より外部加熱強 制循環真空蒸発装置の初の試作品が出品され, 当 時大いに注目された。(1936)

○ソーダ工業へるカランドリヤ効用蒸発装膡とと すに強制循環蒸発装置が続々納入された (1936)

○フルミナソーダ濃縮用として外部加熱型の 5 重 効用缶が作られ， 1 午 $660 \mathrm{~m}^{2}$ のすのは当時として は珍しいるのであった。(1940)
次いで Blow-Knox 式傾斜管型も作られた。

○加㯚が水平から傾斜となりやがて垂直と発展 し, Rober 式垂直管型蒸発器が考案され， ダ ウンテーキを中央にるった標準型ができ，ついで Scott 型のことくダウンテーキを数多くすつ型式 のものへと発展した。(1890〜1900)

○スケールの附着し易いるのに考案されたスクレ パ一附蒸発器があり製塩業としても応用された。 (1900)

○Basket 型垂直管蒸発器がこれより先に 1877 年 に考案作り出されていたが，これを改良し粘着性 の塩類溶液でスケールを生し易いるのに対してボ ンブによる強制循環型が考案された。(1917)

OKestner 型垂直型蒸発器が考案され, 従来のる のに比し管長が管径の 100 倍以上のものが製作さ れるにいたった。(1900)

OKestner 型の变形として落下膜式のすのす考案 され，処理液は加熱管中を上部から落下し下部の 蒸発室に拈い, 発生蒸気と分離し取り出される ものである。(1910)

○製塩用として標準型の強制循環真空 3 重効用缶 が使用され始めた。

○ドイッにおいて外部加熱循環型蒸発器が製作さ れ，真空蒸発装置として使用され，アルカリ溶液 からの食塩の分離に用いられた。(1920)

○大田の塩水蒸発に標準型の機械的循環をさせる マニスティ式の蒸発器が用いられ, Weber式の強 制循環式も広く使用されるにいたった。(1930) OPrache-Bouillon 式垂直強制循環型蒸発器が考 案され，外部加熱式のスクリニーによる機械的循 環のるのからポンブによる強制循環の出現とな り，泡立ち易い粘性の高いすのに使用され始めた。 ○粘度の高い溶液用としてェレメント型が出る。 (1935)

○熱に敏感な溶液に対し落下膜式の蒸発缶が作ら れ、ミルク,シュース濃縮にだんたんと用いられ てきた。(1940) 
1940 1960 終戦を迎え 1950 年頃より各産業がつぎつぎと立 終戦上り ち直り蒸発装置す続々と製作されるにいたった。 $\begin{array}{l:l} & \text { O彆糖工業では, 濃縮結晶缶として従来のコイル } \\ \text { 現在で } & \text { カランドリヤ型の外に, 新しいリングェレメント }\end{array}$ 型が彆作され始めた。(1952)

- ○製塩用として加圧式の 4 重効用の外にエゼクタ 一使用によるオートペーパー法による 4 重効用蒸 発装置が作り出された。(1953)

○パルブ廃液用としてロングチューブのスェンソ ン式の自然循環型が作り始められた。(1954)

○ソーダ, 硫安液濃縮用として外部加熱型のポン プによる強制循環の蒸発装置が続々と慗作されて いる。(1954)

○食品関係では，落下膜式の蒸発缶が試作を始め られ, オレンジ,トマトのシュース濃縮, ミルク の濃縮など熱的に敏感な分解し易い溶液に対して だんだんと使用され始めた。(1954)

○標準型の強制循環下降流式のものが考えられ， 着垢の恐れのあるるの，発泡性の溶液に対して使 用され始めた。(1956)

○製糖用として標準型カランドリヤ式の 1 回通過 の 2 パス型が作られ，従来のカランドリヤ式に比 乙伝熱係数の増大を計り，滞溜時間の減少を目的 としたすのが始めて作られた。(1957)

○廷転翼をむつ筧拌膜式の蒸発午も試作せられ， 高粘度の物質の濃縮に使用され始めている(1957)
○アメリカのルワーによりミルク工場に納入され た筧找落下膜式の蒸発器が開発され, その後食品 関係や高粘度のものに䏍く使用され出した。 (1950)

○亜硫酸パルプ廃液用としてローゼンブラッドー スウッイング式の蒸発缶が作り出され，加熱部が プレート型のヒーターであるため，スケールの附 着を防ぎ，また洗淮が容易であるため，無機塩の 蒸発に使用されている。(1951)

○食品関係では，トマトジュース，オレンジ： ルクなどの濃縮に落下膜式の 2,3 重効用缶が広 く使用されている。(1951)

○ドイッでは，製糖用として，ケスナー式に代わ る Buckow 式の効用缶が考案され，大きな利点を もって実用されている。(1952)

○ウィーガンドールーワー式蒸発装膡が使用され， 糊，ゼラチン，酪農品，尿素，果物シュースの濃 縮に応用されている。これは，落下膜式と䚋找膜 式を組み合わせたもので，除去される水が多量の 場合には優秀である。(1957)

○ルーワー式の改良型として，ハイェル迅速蒸発 器す製作されて拈り非常な成果を上げている(1957) ○オレンシジュースなどの果物のシュース濃縮に 対して，エ゙ぜクターや熱ポンプを用いた落下膜式 の 2 重効用が実用化され，機械的なオートベーパ 一法に比し然料建設費の低下を実証している(1953)

\section{蒸溜薄 置* \\ 新 東 一 郎**}

化学装置にあって, 蒸溜装置は分離および精製操作上 欠くことのできないるのであることは，今更い5，までる ない。この重要な装置の中で, 今日注目の的である石油 精製および石油化学工業の第一段階といわれる原油蒸溜 装置は, 大型化ならびに自動化の点で急速に発展し, そ の規模において他に類を見ない状態である。このような 観点から,ここでは原油蒸溜装置に焦点を合わせ, その 発展の過程を述べる。

わが国では今から約 350 年前に新渴地方に㧍いて，

石油を採取しこれを一種の蒸溜金にかけて灯油を採った と伝えられ, これが石油蒸溜としては世界最初のすのと 考えられる。

アメリカでは約 120 年前の 1840 年代に，やはり灯油を 目的とした石炭または薪を然料として用いる直接加熱式

\footnotetext{
- 昭和 36 年 6 月 26 日受理

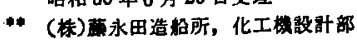

の蒸溜菳が設計され，1850年代まで改良されながら灯油 製造用として広く使用された。1861年になって最初の製 油所が建設されたが, 当時の蒸溜金は石炭乾溜金から出 発したすので鋳鉄で作られていた。その後急激に製油所 が增加し 250 バーレル/日（40 立方米/日）の処理能力 を持つものまで出現したが，作業は主に温度計と比重計 とで製品の性状を規定していたために，運転作業員は 200 人も必要であった。1860 乃至 1870 年には蒸溜金の 材料としてボイラー用鋼板が一般に採用されるよ5にな り,これにとすなって 1 回の処理量が 10 乃至 15 バーレ ルより 100 ハーーレル (16 立方米) に增加した。しかし蒸 溜方法は乾留式であったので, 分溜効果が非常に悪く灯 油溜分の中に軽質分拈よび重質分が相当量混入し, 引火 性がありかつ煤が出易いために, 再蒸溜する必要があっ た。1885 年から 1900 年にかけて潤滑油の利用が盛んに なり，ダルトンの分圧の法則を利用して水蒸気蒸溜が行 なわれ初めた。これがため重質油が低温度で溜出できる よ5になり，油の分解怙よび金底の焼き付くのを防止で きたが,一方ではこのために相当量の水蒸気を必要とし たので，経済的には良いるのではなかった。この問題を 解決しよ5として，まずシアで横置金に真空蒸溜を取 り入れ潤滑油溜分を採取し，鉒残油をアスファルトとす 
ることに成功した。後にオーストラリアです本法を採用 したが，真空装直としては今日一般に使用されている水 蒸気エゼクターと大気脚凝縮器を、組み合わせて用いて いた。一方装置の連続運転に対する関心が高まり，水蒸 気蒸溜鉒を数個值列に連結した連続蒸溜装咱が考案され て，1885 年には工業化されていた。

1905年アメリカに打いて，従来の単独金に分縮器を併 設した蒸溜装置が建設された。このような装置が実現さ れたことは，蒸溜装置の発展史の中で最す革新的な事件 であった。すなわちこの装置は横置円筒型の蒸溜金の上 に直立した分縮器を設置して，金の部分は煉瓦で保温し 分縮器の内部には拳程度の大きさの石灰石が充填されて いた。この分縮器 内では軽質溜分に同伴して上年して いく重質溜分が凝縮して流下し，金へ戻されて精溜効果 が良好になった。分縮器内部に充填するすのは当初石こ ろであったが，その目的を充分発揮させるために，冷却 能力の大きい色々な形状をした金属製のるのが使用され るようになり，金属製で腐融の激しい場合には陶磁器製 のすのが使用された。一方水蒸気蒸溜の場合と同しょう に,この型式の蒸溜金を直列に連結することにより, 連 続運転の可能な蒸溜装置が建設された。

その後需要面の発展炕々もない逐次装眉の処理能力が 增大し, これにつれて分縮器の直径が大くなり充填方 式以外のすのが考案された結果, 圧力損失の小さいハッ プル塔が出現し 1925 年頃始めて使用された。当初は罢 流を使用しなかったために，今日見られるよ5な分溜効 果は当然得ることがでさずあまり好評を博さなかった が，後に還流を採用するよ5になって分溜効果が非常に 良くなり，1930 年頃には 30 段以上のトレーを持つバッ ブル荅が，一般に採用された。

以上述へたよ 5 亿，単独鉒から連続金へと移り変って 熱効率が良くなり，処理能力が增大し，分溜効果も相当 改善されたが，この間に消費側である各種機械類が進 歩し, 品質の優秀なる製品が要求されだした。したがっ て，さらに熱経済的な装置を建設する必要性が生じてき た。このよ5な状勢の下では横眉鉒は

1）熱効率が低い(30 パーセント前後)

2）連続式ではあるが，金内に相当量の熱油を保有し ながら直接加熱するので，油の劣化が進行する。

3）るし鉒板が損傷した場合には，金内の熱油が炉内 に流れ込み大火災となる。

4）この火災を防ぐためには，多量の水蒸気を吹き迈 まなければならない。

5）特にアスファルトなどの重質分を製造する装置で は鉒板の損伤が激しく，頻繁に交換する必要がある。 といらような点が問題とされていた。
1920年に革新的な加熱炬か工業化されて, 従来の蒸溜 装置の様相を一変してしまった。これがパイプスチルの 出現で, 蒸溜装置の発展史の中で特に注目すべきこと である。盉知の通りパイプスチルは長尺の管が炉内に 配置されていて，原油がこの管内を通過するときと外部 から加熱され，蒸溜塔に供給される。これは水管ボイラ 一に做って考案されたるのであるが，多くの問題（管内 の流速, 加熱管の配列拉よび間隔, 加熱管相互の接続方 法など）が当初出てきた。しかしながら設計および操作 上の改善ならびにりターンベンドの出現により実用化さ れ得るようになった。最初の考案者はトランブルで, 1912 年に最初のパイプスチルがカナダで建設された。

パイプスチルと組み合わせた蒸溜塔の造流は塔媔の みならず，塔中段の外部邆流も取り入れ，横置蒸溜金は 完全に姿を消した。1920年頃のことでこれより数年後に は，軽質溜分怙よび重質溜分の両方を製造する目的で， 減圧蒸留を併設した 2 段式のパイプスチルがさらに蜃通 性があり，また熱経済的に優秀なことが証明され，計測 機器の発展 (温度, 圧力, 流量, 液面の自動記録調節計 の出現）といら側面からの応援もあって, 装置は非常に 自動化された。

トランブル式のパイプスチルがアメリカで建設され た頃, わが国です速刻海軍然料廠(徳山) で建設され, 1930 年にはさらに自動化された装置が日本石油 (下松) に, 翌年には三菱石油 (川崎) および小倉石油(横浜)に 建設された。これらの装置の 処理能力は数千バーレル 日程度で, 自動記録調節計を具備しているので運転作業 員は数名で充分であった。

パイプスチルがこのように採用され横置金が姿を消し ていった理由としては, 前記横置金の諸問題点に反して

1) 熱の輻射, 対流, 伝尊が非常に合理的に利用され て，加熱炬自身の熱効率が著しく增大した。

2）原油が加熱管内を通る速度は乱流になるよ5考虑 されて括り(冷油として1乃至 3 米/秒), 局部的な 過熱がされ難い。したがって油の劣化が進行しない。

3）もし加熱管が損傷した場合です，ポンプを停止す れば加熱师内に漏洩する油はごく少量である。した がって，水蒸気を吹き込んで炉内の消火が容易にで き，火災による被害が僅少である。

4) 処理能力が多く，かつ運転条件を一定に保ちつつ 長期間の連続運転が可能である。 などがあげられる。パイプスチルはその後色々な型式の ものが出現し改善された結果, 現在では直立円筒型加熱 炉のよ5に熱効率が 80 パーセント以上す得られるもの が使用されている。

以上述べたよ5な経過で, 今日見られる蒸溜装置の骨 
子ができ坫がったが，一方わが国におけるこれらの蒝溜 装置就よび機器メーカーは，下記のような過程で現在に 打よんでいる。

1921年海軍が艦船および航空機用燃料の必要にせまら れて，外国技術を導入したが，これら装置および機器の 製作，建設にその第 1 歩を印したといえる。すなわち現 在われわれの考えるような装置および機器を製作し始め たのは 40 年前のことで，その後いくつかの装置を手が けたが，第 1 次世界大戦後の経済恐慌, さらにこれにつ ぐ金融恐慌などにより産業活動が不活発になり，需要の ないまま技術的発展す見るべきのがなかった。1931年 満州事変が勃発し民需, 軍需, 両面からの急速な需要の 伸びにつれて，より経济的な装置の設計ならびに機器の 製作とい5 要求の下に成長し，1937年の日華事変，1939 年には第 2 次世界大戦の勃発と, 軍需の占める割合が大 きくなり，国家の援助もあって技術，製作の両面で非常 な進歩を遂げ, 满州, 台湾, タイ国などにまで建設納入さ れた。しかしこの段階における各メーカーは基礎技術の 開発, 研究に柾く, 機器製作および現地建設者として活 動し,エンジニヤリング会社の傾向を持つるのはなかっ た。1945年第 2 次世界大戦が終結し総司令部より各工場 の操業停止および過度経済力集中排除法などの指示があ ク，戦災による縮小飞輪をかけて 1950 年これら制限が 解かれるまで開店休業の状態で, 退化こそあれ発展は望 むことができなかった。しかし一度禁が解かれると、数 年間の空白期間における技術的立ち遅れを速やかに埋め るため，外国技術の導入を行なったのは，止むを得ない 方法と考えられる。このよらな過渡状態が扰さまるにつ れて, 戦前からの技術的な蓄積を基碟として, わが国の 需要に適した装置の研究が，メーカー自身でまたは各種 研究機関と協同で盛んに行なわれ，国産技術の発展を るたらし，優唀なるるのは海外送り出されるまでにな ク, 各社とる単なる機器メーカーよりエンジニヤリング 会社へと移行しつつある現状である。

一方精製蒸溜装置にあっては, 化学工業の発展にとも ない，沸点の非常に接近したるのの蒸溜による分離およ び精製が必要となり，共沸蒸溜，抽出蒸溜特よび超分溜 (スーパーフラクショネーション)の各装置が研究され近 年盛んに採用されだした。

すなわち 2 または多成分系化他の溶剤を添加して共沸 物を生成させ，溶剂添加前には蒸溜による分離が非常に 困難または不可能であったすのを，共沸物の物性を利用 して容易にしたすのが共沸蒸溜である。これはベンゼン
によるエタノールの脱水法に端を発し（ヤングの考案）, その後オスマーの考案した酢酸ブチールによる㼍酸水溶 液中から醀酸の回収など，衆知の共沸蒸溜装置が多く使 用されている。

一方 2 または多成分系にこれらの系と比較して沸点の 高い溶剤を添加することにより，単一または多数の成分 との親和力を起こさせ，これらの系本来の気液平衡関係 を変更して比揮発度を大きくし，分溜を容易にしたすの が抽出蒸溜である。抽出蒸溜装置としては, ブタンとブ テレンの分離怙よびペンゼン, トルエンの精製にフェノ ールを採用したものが有名で、シクロヘキサンの精製に あ採用されている。

つぎに超分溜であるがウレンの定義を借りれば，全還 流の場合の理論段 数が 30 段以上を必要とする場合と している。また一般に製品の純度が 99 パーセント以上 で，分溜されるべき成分の比揮発度が 1.5 以下としてい る。この実例としてはエタンからエチンン,プロパンか らプロピレン, ノルマルブタンからイソブタンの分離な ど多くあるが，上述した共沸抢よび抽出蒸溜装置と併設 されることが多い。

フイリップスのキシレン分離装置を例にとると，結晶 分離装置と組み合わせているが，350段，200段，150段 50 段の各塔があり，合計 750 段もの段数となってい る。この内で 50 段の脱メタキシレン塔を除いて, 他はす へて超分溜塔と考えられ，構造上塔の高さの制限や圧力 降下の問題から 1 塔では製作不可能なる場合には，2塔 またはそれ以上の塔を直列に使用している。

このように段数が多くなり, 処理量が增加して塔径が 大きくなるにつれて, 棚段の圧力降下, 段効率, 処理能 力などの研究が進められ, 従来のバップル怙よびパーホ レイトトレーの外に, カスケード,ターボグリッド, シ エット,フレキシ怙よびフロートバルブトレーなどが採 用されてきた。これら型式のトレーには構造が非常に簡 単なものがあり，塔内容物の重量を軽減させるばかりで なく，特殊材料による製作が可能となり，耐蝕および而 熱性を持たせることができて，長期連続運転に対しても 有利になった。これは塔内容物のみならず，金属材料括 よび熔接技術の進歩により，塔本体の構成材料として 特殊金属または金属のクラッドスチールおよびライニン グたと党ば 13 クロム，18-8 ステンレス，チタン、モ ネルなどが採用されて装置の寿命を大巾に延長し製品の 污れを减少するのに役立っている。 


\section{乾 蜗 茈 量*}

高橋 敢 一**

\section{緒 言}

乾燥操作は工業的に非常に多くの分野にわたってとり 入れられているものであり，それゆえにこれまでいかに すれば材料から水分を最子経済的に除去できるかといら ことが考えられてきたし，今後もまたこの考光にそった 乾燥工程が当然とり入れられるである3。乾燥の対象と なる材料の形状, 特性は非常に多㞳にわたるため, 各種 材料に適合する乾燥装置を選ぶことが最も重要なことで あるのは当然である。

近年にいたって溸く各種材料に適合した種々の形式の 乾燥装置が使用されだしてきたが，初期においては，天 日乾燥, 棚段式箱型乾燥器, トンネル乾燥器, あるいは 回転乾燥機によってほとんどすべての材料が処理されて いた。戦後, 食品, 薬品, 化学肥料, 合成樹脂などの粒 粉状製品が生産されるよ5になり,これらを乾燥するに 適した気流，噴霧，通気バンドおよび通気回転，熱風受 熱溝型擋找, 水蒸気加熱管付回転, 流動などの各種乾燥 装置が抬頭してきた。

\section{1. 乾燥装置発展の経過}

各種材料の乾燥法は種類が多いが, そのほとんぞは起 源が古く, 戦後新しく出現したものは, 凍結乾燥, 赤外 線乾燥, 高周波乾燥, 流動乾燥にすぎない。

戦後最むよく使用されている気流乾燥装置は, おそら く 1920 年代にその起源をるつるので, 1930 年代になっ てすでにドイッで工業化されているがその後発展しなか った。しかし戦後 1949 年にアメリカのCombustion Engineering 社によって, 解啸, 粉碳をともな5型式のす のが紹介されたのを緒として今日では種々の型式のもの が極めて広範囲にわたって使用されており，戦後の建設 台数は数百基に打よんでいる。噴第乾燥は，すでに1860 年代にョーロッパに括いて起っているが，工業規模の装 直は 1910 年代に完成され，1920 年に入って，粉乳用の ものが，わが国へはじめて導入された。戦時中には，野 戦食糧として, 粉末状の味噌, 醬油の製造に利用された ことがある。現在はまだ回転円盤噴第方式のすのが多く 数十基嫁動している。材料摫找型の乾燥器では, 回転乾 燥機が当初は主として石炭, 石灰石, 鉱石などの乾燥に

** 昭和 36 年 8 月 1 日受理

* (株)栗本鉄工所 設壾第 1 部
鉱山機械として使われていたが近年にいたりここれが大 量処理が可能であり，運転が安定していることのために， 性能があまりよくないにるかかわらず，化学肥料，合成 樹脂, 食品などの乾燥にす使われるよ 5 になり, 気流乾 燥とならんでよく普及している。また承蒸気加熱管付き 回転乾燥機は,ルイビル スチームチューブドライヤー として知られているが，これは 1900 年頃に General American Transportation Corporation に拉いて製作さ れたもので, 現在まで種くの化学製品, 食品などの乾燥 にアメリカをはじめとして広く使用されている。1957年 以降，わが国に扮いてす製作されるようになった。回転 通気乾燥機はロートルーバードライヤーとして知られる ものである。すでに 1930 年代末期にその工業規模のる のがスエーデン, イギリスで木材チップ, パルプ屑の乾 燥などに使用されているが，わが国では現在ですほとん ど使用されていない。つぎにラピッドドライヤーとして 知られる熱風受熱溝型筧找乾燥機は, 第 2 次大戦中から 戦後にかけて, ドイッに拈いて発明されたもので, 1948 年に西ドイッ Hazemag 社において製作され,ドイッ,イ タリーをはじめとするヨーロッパ諸国で主として石炭、 石灰石, 高炉㳯などの乾燥に使用されてきた。1954年以 後においては，わが国法扮いても製作され数十台が運転 されている。バンド型通気乾燥装置も起源古く 1930 年 代にすでに紹介されている。始祖はアメリカの Proctor \& Schawartz Inc. であるが, 顔料, 粘土, 樹脂チップ 㵶維類などの乾燥にわが国に打いてもかなり製作され使 用されている。流動乾燥は, 第 2 次大戦当初アメリカに 扣いて石油の接触分解に流動層を応用したのを契機とし て榦燥に対しても種々研究されだしたもので，わが国に 怙いては流動層を多段化することが考兄られ独特の乾燥 装置が発明されている。また最近では; 横移動の流動層 を利用する乾燥装置も紹介されている。最後に涷結乾燥 については, 生理学, 医学の面で1900年の初期より血清, 酵母, ヴィルスなどの保存にこの方法を用いて成功をお さめて拉り, 第 2 次大戦中に, 血漿, ペニシリン, スト レプトマイシンなどの乾燥製品の製造に成功し以後工業 化されるようになった。

\section{2. 乾燥技術の進歩}

乾燥装置の能力は, 一定の乾燥器容量に打ける材料へ の伝熱量の大きさによって決定されるから, 所要の熱 量を与えるのに必要な容量が小さいほど能力が大きいと いえるわけである。乾燥装置の容量を小さくするために は，i熱容量係数を大きくする。ii)乾燥速度を大きす ることが必要であるから，これらの条件にかならような 乾燥法が種々研究され、これにともなって乾燥装置が進 
歩してきた。熱容量保数, 乾燥速度 の大きさは主とし て熱風と材料との接触方式によって決まるすのであるか ら，この接触方式の変化はそのまま畭燥装置の進歩につ ながるといえよう。

この具体的なあらわれは, 並行流の箱型およびバンド 型乾燥器, 回転榦燥機などから, 通気流のバンド型拉よ び回転型乾燥器あるいは熱風受熱清型擋抖, 気流, 流動 層などの熱容量係数あるいは乾燥速度の大きい乾燥装置 への移行にみることができる。またこれらとは別に，熱 に敏感な材料を処理するための涷結あるいは真空乾燥 器, 熱伝導によるため熱効率の高い水蒸気加熱管付回転 乾燥機, 原液より一挙に粒粉状製品をらることのでさる 噴霧颙燥装置など特殊な材料に対するものもおのおの進 歩してきた。表 1 亿参考までに各種乾燥装置の熱容量係 数をあげる。

表 1 乾燥装置の熱容量係数

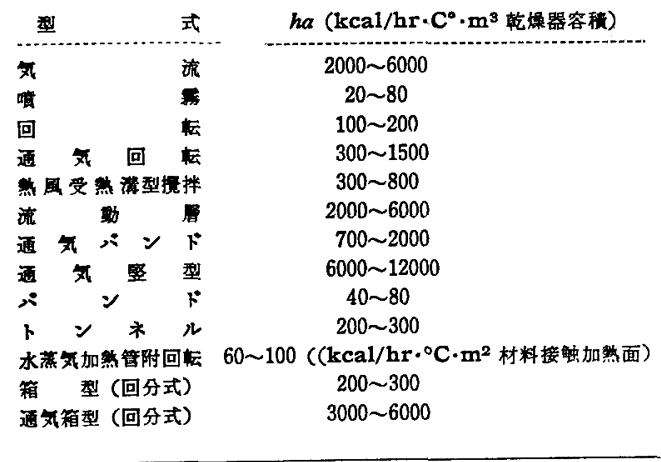

\section{3. 今後注目される乾燥装置について}

今後注目される乾燥装置についてのべてみたい。

a) 気流乾燥装置操作が容易で構造も極めて簡単 であるので今後すますます使用されるるのと思われる。 本装置は乾燥管の他熱風発生装置, 材料供給装置, 集 塵装置, 排風機などより構成されるすのであるから，本 装置の発展はこれら付属設備の進歩に負らところが大き い。したがって今後特に付着性, 粘結性の大きい材料を 処理し 5 る材料供給装置, 高能率の乾式集塺装置が出現 すればさらに用途は桩まろう。

b) 喷霜乾燥装置 近年, 粉乳, 合成洗剂, 合成樹 脂, 化学肥料, 工業薬品などの粒粉状物の需要が急激に 增加してきたため脚光を浴びてきた。

夜状原料から, 濃縮, 成型, 粉破などの工程を省略し てただちに粒粉状製品をらることができるが，蒸発負荷 が大きく, 噴籍方式が回転円板による場合は, 製品粒径
が決まると，供給量とは無関係にある一定以上の塔径が 必要となるなどの不利な点があり，特に後者は，噴霧乾 燥に和いて熱容量係数が小さいことの主な原因であり， また少量処理が不経済であることの原因でもあるので， 今後いかにして塔径を小さくするかが重要な課題となろ う。また製品粒径の大きいものが要求されてくると回転 円板噴䙳ではますます塔径が大きくなるので加圧ノズル による噴霧方式が注目されてこよう。そしてノズルの進 歩によって任意の噴籍角度で希望粒径の粒子を噴霧でき るようになれば塔径を小さくできるから、ノズルの発展 が期待されるわけである。さらにノズル噴霧によれば向 流操作るでき粗大粒子の乾燥にる好都合である。将来は 加圧ノズル向流式のるのが多用されるようになろう。

c) 通気回転乾燥機処理能力が大きく，運転に安 定性のある回転乾燥機の利点と熱容量俰数を飛躍的に增 大せしめる通気乾燥の利点とを組み合わせたもので，口 一トルパードライヤーとして知られるものが多い。構造 は図 1 に示すごとく，回転円筒内に傾斜をるつ多数の羽 根があり,この羽根によって仕切られた内外円筒の間の 環状部より吹き込まれた熱風は材料層を強制通風して排 気される。”材料は羽根の上を傾斜にそってすべりながら 出口へと進む。回転乾燥機にくらべて熱容量係数が大き いので，今後用途が拡まっていくものと思われる。

d) 水蒸気加熱管付回転乾燥機 図 2 のごとく回転 円筒の内側に同心円状に水蒸気加熱管を $1 \sim 3$ 重に乾燥 機全長にわたってとりつけ，加熱管からの熱伝導によっ て乾燥するるので, 直火式回転乾燥機に比し, 蒸気によ る間接加熱のため一定温度で乾燥でき, 蒸気圧力によっ て温度は決まる。また熱の移動は伝導を主とするため熱 効率が高い。処理能力は, 直火式の約 3 倍に達するが, 建設費が高くつく。機内よりの排出空気量が少なく, 低 温操作が可能であるので将来は溶剂回収にる利用される ものと思われる。压扁大豆, 木粉, 重曹, グルテンなど のフレーク状, 粒粉状材料などの乾燥に適している。

e) 熱風受熱满型鞋汼乾燥機图 3 亿示すごとく断 面が卵型の短い胴体の底に 1 本または 2 本の回転軸を設 けこれを高速回転せしめて材料を上部にはねあげ熱風と 並流に接触させながら乾燥する。胴体は仕切り板によっ て小室に区分されているので各室では熱風と材料とがは げしく混合するため熱容量係数が大きい。高温ガスを使

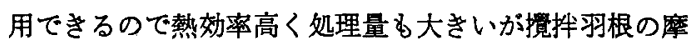
耗があり，運転動力が若干大きい。また材料の破壊を拈 それるすのには使用できないか゚全般的には性能がよいの で今後の発展が注目される。

f）流動乾燥装置 装置型式は堅型と横型に大別さ れる。㹂型には多段のものと 1 段のすのとがあるが製品 


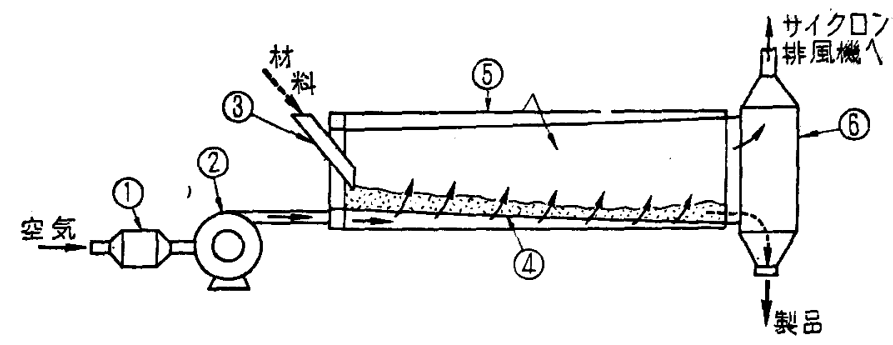

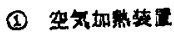

(2) 送風机

(3) 材料投入シュート

(4) 倾除羽根

(b) 胴体

(C) 出ロフート

因1通気回枟乾媒機

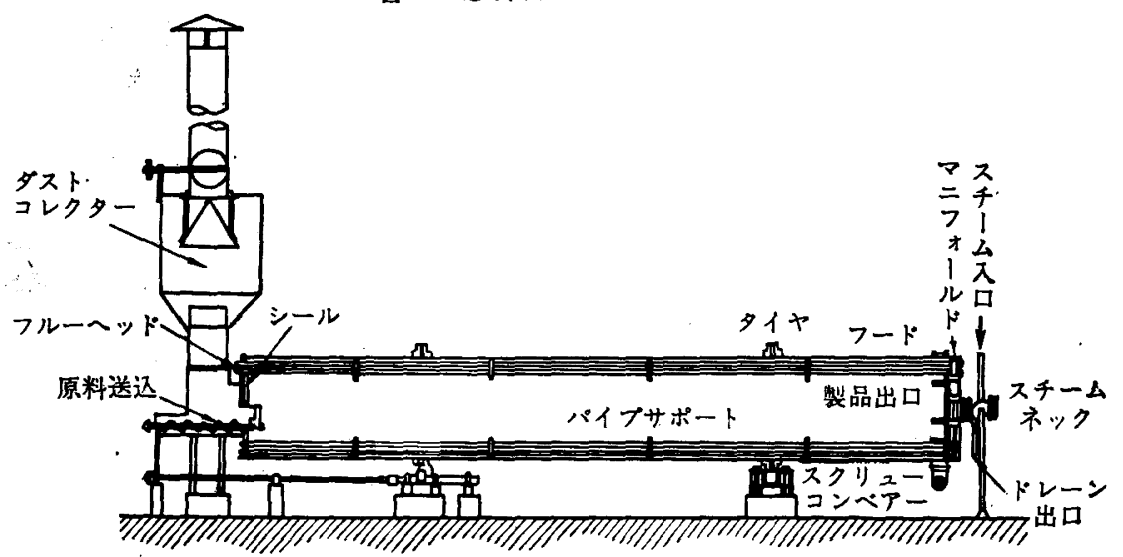

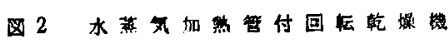

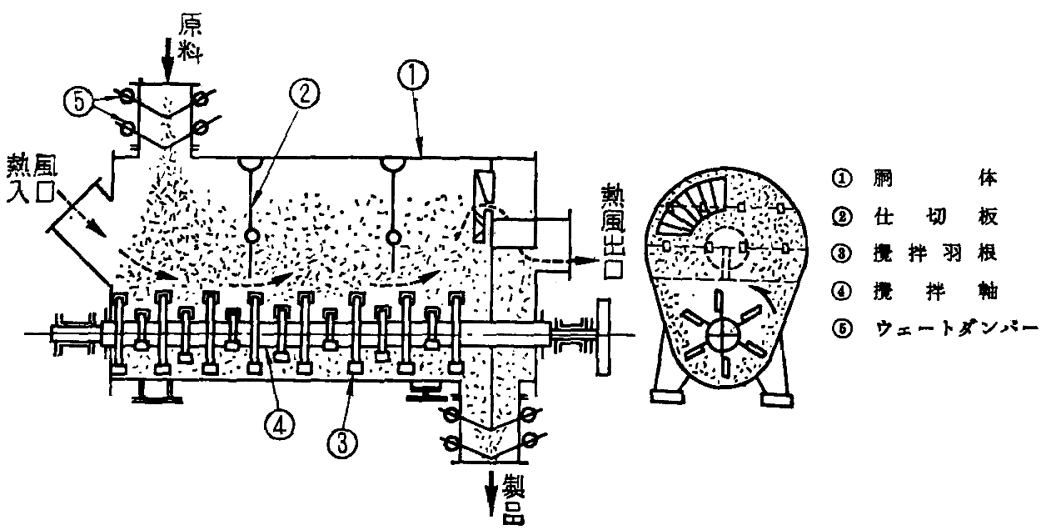

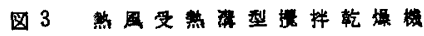

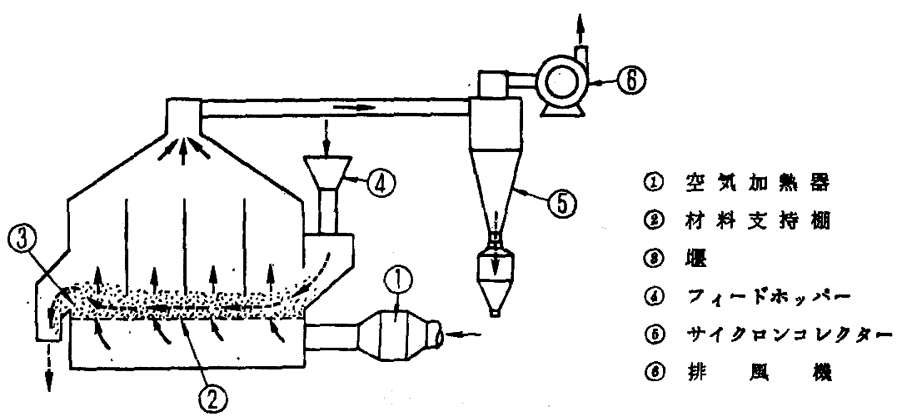

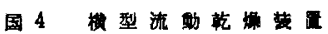




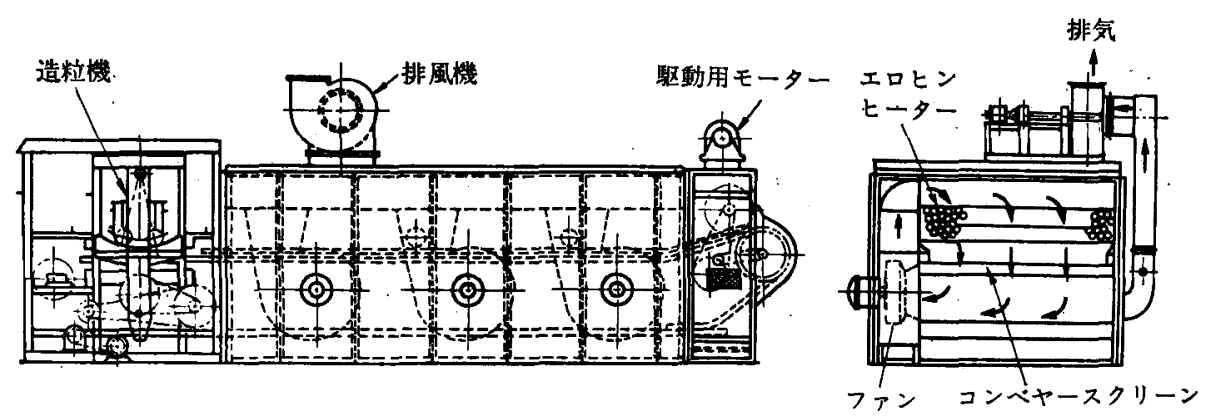

因 5 バンド型通気乾燥装

を低含水率にし，颙燥ムラをなくするためには多段の方 がすぐれているので当然多段化に進むべさである。この 場合いかにして上段より下段に円滑に材料を移動させる かが最も問題となることで今後もこの方向に力が注がれ るすのと思われる。横型は図 4 のごときすので水平連続 多室流動層装置とよばれ，粒粉状材料の乾燥のほか冷却 にも適する。材料は仕切り板と金網との間隙を通って 移動し，仕切り板によって十分混合されながら乾燥をう け，出ロより連続的に排出される。可動部分がないため 構造が簡単で運転が安定している。熱容量係数が大きい ので今後の発展が注目される。

g）パント型通気乾燥機＼cjkstart金網コンベヤー上に，熱 風が通過しらる空吵をるって材料を充填しこれに熱風 を強制的に循環通気せしめて翰燥する。乾燥材はいくつ かの小区分に分かれ各区分毎に熱風は循環していて 1 部 排気される。材料はコンベャーにのり静止状態のまま連 続的に機内を通り排出される。乾燥時間が短く装置は小 さくてすみ，材料の破壊，飛散がない。通気回転では処 理できない酸化チタン, 炭酸マグネシウム,リトポン, シリカゲルなどのフィルターケーク状材料のほか, 䋐維 状材料, フレーク状材料にる使用できるので，主として この方面に用途が拡がらう。

h) 凍結乾燥器被乾燥物を凍結させ, 真空中でこ れを急速に年華させて乾燥するため一般の乾燥と異って 複雑である。このため工業装置は建設費が高く（主とし て真空装置が高価), 大量の連続処理が困難な現状であ り，基䂭資料，工業資料ともまだまだ不十分であるが， 低温乾燥であるため物質の破嘖とか変性がないなど種々 の優れた特性をるつので, 最近の真空技術の長足の進歩 によって, 今後は, 野菜類, 肉類. 調味料などの食品工 業, 微生物, 抗生物質,などの蒋品工業などをはじめと して広範用にわたって使用されるようになるすのと期待 される。

\section{吸収装贯・抽出装量*}

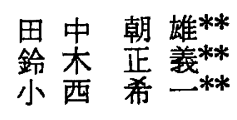

\section{1. 吸收装豆}

吸収は 1 世紀以上る前化学工業の発生と共に用いられ てきた操作であり, 化学工学の単位操作としては蒸溜と 共に古くから最も力を入れて研究されてきた。吸収は酸・ アルカリ工業を始めとしてアンモニア，メタノール工業 および石油工業の多数の製造工程中に主要な操作として 用いられているが, 次に 2,3 の例について過去 25 年 間の進歩の跡をみてみたい。

塩化水素ガスの吸収による合成塩酸製造に扰いては， 吸収装置として戦前は熔融シリカ製の吸収舟を多数水平 に連結したものを用いてきた。戦後 1948 年にアメリカ に批いて不渗透性黒鉛 (Impervious graphite) 製の吸収 塔が用いられ始めたが，黒鉛のるつ優秀な熱伝導性，機 械的強度, 加工性, 耐蝕性等のため, わが国においてる 国産材料を用いて一般に普及し生産の効率を上げるのに 役立っている。黒鉛製吸収塔は，また BHC 製造にも用 いられている。

硝酸製造工程に扎いて, $\mathrm{NO}_{2}$ ガスの吸収を加压下で行 えば常圧時よりも有利であることは早くから知られてい たが，耐酸性のクロム鋼の発達と共飞耐酸・耐圧の吸収 塔の製作が可能となり，わが国において加圧吸收のフォ ウザー式がすでに 1937 年に導入され，さらにこれを改 良した新フォウザー式が 1958 年に採用され従来の常圧 吸収式と切り換えを行なっている。

戦後の肥料工業合理化のため合成ガス製造のガス源転 換の問題がわが国で大きくクローズ・アップされてきた

* 昭和 36 年 9 月 26 日受理

**千代田化工建設（株） 
が、これに伴ないガス精製部門においても検討が行なわ れた。炭酸ガス除去においても従来は高圧水洗滌による 吸収が一般に行なわれていたが, 1956 年頃より MEA 法, 熱炭酸カリ法, ベトロコーク法などを採用し始めてき た。MEA 法牥アメリカにおいて古く 1929 年にはじめ られたものであるが，モノェタノール・アミンと炭酸ガ スと反応してカーパメイトまたは炭酸塩が生成し，これ を加熱すれば分解して炭酸ガスを分離して容易に再生が 行なわれることを利用したものである。この方法の利点 としては, 高圧水洗涤と比較してガス压縮前に炭酸ガス 除去が行なわれ，炭酸ガス吸収の選択性が良いため副産 炭酸ガスの純度が高いのでドライ・アイスまたは尿素の 製造に用いられることであるが，欠点としては，蒸気消 費量が比較的多い。熱炭酸カリ法は，1954年にアメリカ の鉱山局より発表されたもので, MEA 法に比較して, 吸収・再生共に同一温度で行なわれるため液々熱交換器 が必要でなく，かつ蒸気消費量, 冷却水量が少なくてす む。適用範囲として，炭酸ガス濃度 $10 \%$ 以上が最も良 いので, 最初高濃度の場合熱炭酸カリ法を用い, 次の微 量除去の場合にッーダ水法, 安水法, または MEA 法等 の何れかを併用する。熱炭酸カリ法の最も本質的な欠点 は炭酸ガスの吸収・放散速度が比較的遅いことであるた め, この反応を促進する触媒または活 性剤の発見を試 み、ごく少量の有機物をたは無機物の添加が有効である ことを利用したのが，最近イタリヤで開放されたべトロ ニーク(Giammarco Vetrocoke) 法である。このプロセ スでは, 三酸化ヒッ等の少量を熱炭酸アルカリ溶液に添 加したものを吸収剂として用い吸収・放散速度を著しく 增大しているので熱炭酸カリ法に比較して四収塔打よび 再生塔が小型であり水蒸気消費量も少ない。また，三価 のヒソは強力な腐食に対するインヒビターであるので炭 素鋼製の装置でる腐食が認められない。1960 年に発表 された Fluor 社の方法は, 高圧水洗滌の低熱エネルギ 一費と MEA 法の低動力費とい5両者の長所と併せる つことを目的として開発されたもので，溶剤として無水 で反応性のない有機物(炭酸プロピレン,グリセロール。 トリアセテート等）を用い前三者と異り化学吸収でなく 物理夢収に基礎を怙いていて, ことに $3 \%$ 以上の出口炭 酸ガス濃度の場合有利である。

天然ガス，精油所ガスより軽質炭化水素の呂収による 回収は, 戦後 LPG の需要の增大からわが国でも行なわ れているが, アメリカでは 1948 年頃より吸収とストリ ッピングの結合方式一Fractionating absorber一が用い られている。これは原料ガス中にメタン、エタンなどの 低沸点成分が多いときプロパンの収率を上げるため 1 本 の塔の上部で吸収を，下部でストリッピングを行なわせ
たものである。

次に吸収装置の発達について述へてみよ5。充填塔は 最も古い吸収装置であり，充填物として古くはコークス， 呼石などを用いたが，ラシヒ・リング，レシング・リン グ，鞍型，格子組などが広く用いられ，材質も陶器，金 属，黒鉛などと多岐に亘っている。最近ではプラスチッ ク製の充填物むアメリカに扰いて発表されポリエチレン 製の Tellerettes 型 (1959)，ポール・リングなどはそ の例である。层統的に吸収には多く充塤塔が用いられて きたが，石油・天然ガス工業では段塔とくに泡鐘塔が早 くから用いられた。一般には小型装直では充荟塔大型を 要するときは段塔がよいとされているが炭酸ガス洗㳻塔 の例では直径 $2 \mathrm{~m}$ 以上の充塤塔が使われている。近時蒸 溜用の段塔として従来の泡鐘塔に代って目的によって は種々の型の段塔たとえば多孔板塔, Turbogrid 型, Kittel 型などが次第に用いられ始めてきたが吸収・スト リッピング用としても使用できる場合があると考えられ る。分散型の吸収装置として, 古くよりあるスプレイ 塔, サイクロンスクラバ(1935), および近年発達したべ ンチュリスクラパ(1948 年)，エゼクタスクラバなどは， 接触面積は大きいが表面更新度が低いので, 溶解度が大 きく移動単位数が小さい場合に用いられ，たと六隹固体 粒子を含む極めて溶解しやすいガスを吸収するときなど に好適である。また，最近遠心式または回転式などの機 械的吸収装置の研究む行なわれ，従来の装置飞比較して 高能率・小型の装置を開発しょうとする傾向が みられ る。(小西)

\section{2. 液々抽出装置}

液々抽出操作は, 実験室的には古来よく用いられる手 段であるが，工業的に大きく利用され始めたのは比較的 新らしい。1909年（明治 42 年）ルーマニアの Edeleanu によって，液化 $\mathrm{SO}_{2}$ による石油中の芳香族成分の選択的 抽出の原理を応用した灯油精製法が始まって以来, 非常 に広く普及したが，これが潤滑油の精製にまで応用拡大 されたのは漸く 1930 年（昭和 5 年）であった。1930年 代は，石油精製に剧ける液々抽出の万華鏡時代で，フル フラール法, フェノール法, プロ パン脱整法, デュオソ ル法, ハシリソル法, 溶剤脱䁽法, その他各種の組合せの 液々抽出による潤滑油の精製法が提唱された。

わが国において初めて採用された溶剤抽出精製法はフ ルフラール抽出法である。昭和 12 年日本石油株式会社 は技師をアメリカに派遗してその実際を調査研究せしめ て, これを採用し下松製油所に建設して，昭和 15 年 9 月完成稼働させた。最初はアメリカより輸入したフルフ ラールを用いたが，国際情勢の悪化により輸入が杜絶し 
てからは徳山ソーダより少量のフルフラールを購入し， かろうして操業を続け，当初は航空潤滑油の精製を目的 としたが成功せず，戦車用潤滑油の製造にとどまった。 その後北海道に日本ブルフラール会社の設立を計画した が，工揚建設途上終戦となり，同社は解散された。

フルフラール装置は前記日本石油下松製油所と相前後 して朝鮮石油元山製油所认拁いてる建設し，また昭和18 年日本石油秋田製油所が鉄道省の要請によって過熱シリ ンダー油生産のため本装置を完成したが，終戦前夜の空 翡によって壊隇した。

フェノール法は昭和 15 年徳山海軍燃料廠，昭和 17 年 四日市海軍然料廠がそれぞれフェノールとクレン゙ールの 混合溶剂を用いる装置を建設したが，共に戦災を蒙った。 デュオソール法は昭和 16 年昭和石油株式会社（当時早 山石油）が川崎製油所に，また丸善石油株式会社が下建 製油所にそれそれ建設，現在稼働中である。

溶剤脱蝶法は昭和 14 年日本石油下松製油所飞おいて アセトンと工業用ペンジールを用いる BK 脱䗰装置を建 設したのがわが国最初のすので, その後メチルエチルケ トン(MEK) を用いる法，これら溶剤による脱㱬法，ア セトンのみを用いる法, 各種ケトンと芳香族炭化水素の 組合わせによる法，アセトン・ベンゾール混合物から水

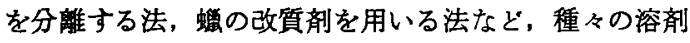
脱䗰法に関する特許が生れるに至った。

バリソール法は昭和 13 年小倉石油（現日本石油精製 横浜製油所）の採用したものがわが国最初である。続い 乙昭和 14 年昭和石油株式会社（当時早山石油）が川崎 製油所に，丸善石油株式会社が下津製油所に，また徳山 海軍然料廠にそれぞれ建設され，さらにやや遅れて朝鮮 石油元山製油所, 岩国陸軍然料廠などに本装置が建設さ れた。これら諸装置は日石横浜, 昭石川崎を除き,こと ことく戦禍を蒙り, 日石横浜の同装置は昭和 25 年解体, 大協石油に売却され，さらに 30 年垔細重石油に僙渡さ れている。

プロパン脱曆法は昭和 15 年徳山海軍燃料廠に建設さ れたのがわが国最初である。続いて昭和17年四日市海軍 然料廠に，18 年日本石油秋田製油所にそれぞれ建 設さ れたが，何れる戦禍のため廃亩となった，戦後は昭和 27 年, 東亜然料工業株式会社和歌山製油所氏，同 30 年日 本石油精製横浜製油所にこの装置が完成された。

戦後に括ける高級潤滑油の製造法は, フルフラール抽 出, フェノール抽出とプロパン脱歴, プロパン脱臘, ベ ンソ゚ール・ケトン (MEK) 脱臘法が主体となり, 雨後の 筍のごとく提唱された諸法は次第に整理されて今日に至 っている。最近新しく石油工業に導入された液々抽出の 技術で注目すべもののジェチレングリコールKよる芳
香族の選択的分離法で, アメリカの U.O.P. 社と Dow Chemical 社の共同開発になる Udex 法であろう。本法 は昭和 32 年三菱石油川崎製油所化設されて以来, わ が国における芳香族分離工程の中心的プロセスとなっ た。石油製品からマーカプタンを主とする硫黄化合物を 抽出除去する方法るまた 1930 年代から発達し, マーカ プタンの苛性ソーダ水溶液に対する溶解度を高めるため の各種ソリュータイザーの発明, あるいは, メタノール などの溶凧の発見によって完成された。

石油工業以外の分野に淤ける液々抽出の応用は比較的 少い。しかし, 近年の抗生物質生産の增大は, この方面 に抢ける液々抽出工程の主要性を決定的とした。また核 物質分離に打ける液々抽出の主要性は今後さらに拡大さ れるであろう。

抽出装置としては, 初期のエデレアヌ法やデュオソル 法に見られるごとき Mixer-Settler 型のものから充填塔 による向流接触などに変って来たが，その後いろいろの 抽出塔が提唱された中で， RDC 型(回転円盤型)液々向 流抽出器は潤滑油の精製, 脱歴の分野に威力を発揮し, また脉動式抽出器す今後大いに発展を約束された装置 で，原子力工業の方面て活発な研究がなされている。抽 出装置の特異の型式としては，Podbielniak 式の遠心接 触装置で, 小型の装置で比較的大容量, 高接触段数が得 られところから，抗生物質工業に拈ける液々抽出，ある いはコールタールからある種の成分を単離する場合など の方面に，わが国でも戦後相当数輸入された。（鉿 木）

\section{3. 固体抽出装置}

固体中の有用成分を液体溶剤飞よって抽出する操作 は，古くから捈業に怙いて有用金属を鉣石から取出すた めに用いられた。たと竞ば金を青化ソーダで，銅を硫酸 またはアンモニヤ溶液で溶出したなどである。また小規 模なものとしては花から香料がアルコールで抽出されて いる。しかしわが国に和いて最も広く大規模にかつ工業 的に抽出操作が用いられたのは植物種子からの油の採取 であろ5と思われる。したがって過去 25 年間の固体抽 出操作の発展史を代表するものは, 植物油の抽出装置の 変遷であろらと思われる。

25 年前といえば, 昭和 11 年頃である。この頃まで は大正の始めに今の豊年製油がドイッよりバッテリ式大 豆抽出装置を輸入し清水に建設したのを皮切りに，次い で大正 7 年頃日華油脂が若松にバッテリー式を設置し たこのバッテリー式が現在まで続いて全国 70 社近い 植物油製造会社に，使用されているのである。一方バッ テリー式に対して，連続抽出が考兄られ昭和 12〜13年 頃に，满鉄中央試験所に打いて佐藤正典氏の指導の下に 
アルコールによる大豆油の抽出実験が行われ，スクリュ ーコンベャータイプのパイロットプラントが建設された が, 粕の粉砕, 目詰りのため困難が伴い遂に終戦となっ て日の目を見なかった。昭和 14 年頃吉原製油の木本氏 らがV字型連続抽出装直 $50 \mathrm{~T} / \mathrm{D}$ の開発に努力され独自 の吉原式連続抽出装置が完成した。

連続抽出装置はその後各社で研究されたのでするが， 今次終戦までにとくに見るべきすのもなかった。終戦後 諸外国の連続抽出装置の情報が入手出来るよ5になるに 及び外国よりの宣伝もありわが国の化学機械メーカー中 にもこれに注目し，千代田化工建設が昭和 27 年四日市 の安藤製油に 30T/D のL型連続抽出装置を建設した。 これは水平コンベャー型のデスナット式と㹂型バスケッ ト型のボールマン式に範を取った。パーコレーション十 イマージョン+パーュレーションのタイプのbので, そ の外観がL型をなしている。メーカーが作った国産連続 抽出装置の第 1 号である。これより次第に各製油会社も 連続抽出装置に注意を向け始めたか，昭和 30 年頃より デスメット(ベルギー)，ルルギ(ドイッ)ブローノック スのロートセル型(アメリカ)などの各連続抽出機メーカ 一のわが国に対する売込みが漸く激しくなり，また技術 革新の声も高く，さらに大豆の AA 制等貿易自由化の波 あ押し寄せて来たので，各製油会社はその対策として， 競って連続抽出装置建設に踏み切った，しかしそれらの 建設はまだほんのここ 4 〜 年来のことであり，また一 流製油会社が主である。大体次のよ5な状況である。

\begin{tabular}{|c|c|c|c|}
\hline 昭和座莱 & ロートセル & $100 \mathrm{~T} / \mathrm{D}$ (大豆処理能力） & 昭和32年完成 \\
\hline 量年製油 & ロートセル & 200T/D (大豆) & " 33年 / \\
\hline 味の菜 & ルルギ & $350 \mathrm{~T} / \mathrm{D}$ (大豆) & 34年 / \\
\hline 日本興油 & ルルギ & $50 \mathrm{~T} / \mathrm{D}$ (大豆) & 34年 / \\
\hline 熊沢製油 & ルルギ & $100 \mathrm{~T} / \mathrm{D}$ (大豆) & 35年 / \\
\hline 不二㱔油 & 千代田式 & $100 \mathrm{~T} / \mathrm{D}$ (大豆) & " 35年/ \\
\hline 安葄慗油 & ルルキ & $150 \mathrm{~T} / \mathrm{D}$ (大豆) & 昭和35年起钤中 \\
\hline
\end{tabular}

その他 20 50 T/D の小型連続抽出装置には, 吉野式, 田端式など, 数基宛建設されている。また千代田化工は $20 \mathrm{~T} / \mathrm{D}$ の大豆連続抽出装置一式を沖繩に輸出建設し成 功し，共立化工機はブラジルに一基を建設した。

ハッテリー式は, とす角として連続抽出式の概略を説 明すれば，わが国に建設された連続抽出装置はほとんど 外国のものであるが，まず最初に考えられたのが，スク リューュンベャータイプ（ヒルデブラント抽出機その他 多数）および特殊コンベャータイプ（ボノトーミミアー グ，ケネディーなどの各抽出機）であるが，いずれる向 流イマージョン式でミセラ濃度を高めるが, 困難かつ原 料に比し溶剂を多量に要した。次いでバケットェレベー ター型のケージを有する堅型抽出機(ボールマン抽出機) およびスクレーパーを有する多段棚塔式（ボーム抽出機 その他）が開発されここでパーンレーションシステムが
採用された。多段棚塔式はスクレーパーによる粕の钽粉 化および底金網の目詰りを起す恐れが多い。その後これ らの欠点を補うよらに工夫されたのが，現在わが国で採 用されている千代田式ロートセル，デスナット，ルルギ の各抽出機である。ドートセル抽出機は, 水平円回転を する金網底の数個の扇形ケージを有する抽出機でパーコ レーションを主としイマージョンをす行い得る。デスナ ット抽出機は側壁を有する金網ベルトコンベャー式でパ ーコレーションを行う。ルルギ抽出機は水平移動の金網 底バスケットコンベャー式でパーュレーション，イマー 浔ン併用式でありとくに最新型はその金網底がバスケ ットケースと别個に運行をし, 全バスケットを有効に使 用するよ5に工夫されている。これら 3 者はいずれす容 剂の㮩環パーコレーション法を採用して最終ミセラ濃度

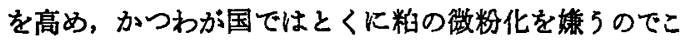
れに対処するため䊉はバスケット中に静止のまま排出口 まで移動するようになっている。

これらの連続抽出装置が現在最す進歩した装置と認め られているので, それらの $100 \mathrm{~T} / \mathrm{D}$ 大豆処理程度の装置 の保証運転值を举げれば，大体次のよ5である。

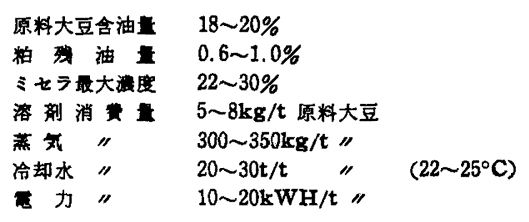

（田中）

\section{ガス分離装億*}

\section{門 奈 五 兵**}

標題のガス分離装罡として梁冷ガス分離である空気分了 離装置とガス分離装置の 2 種類をとる。

これらのガス分離装置に対する国内メーカの過去 25 年にわたる新規製作装置の展望は年表の通りである。以 下空気分離装置とガス分離装置に分けて述べ。

\section{1. 空気分離装罾}

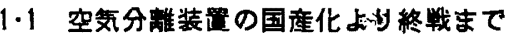

わが国における酸素工業は明治 43 年 (1910 年) から 始まりアンモニア合成工業す大正 3 年 (1913年) から始 まったが，それに用いられた空気分離装置はいずれす， ドイッやフランスから輸入された。

昭和の始めにいたり、日本酸素や神戸製鋼が国産の空 気分離装置を製作する研究を始めた。

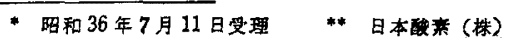


日本酸素は昭和 7 年複精留式酸素分離装置の研究製作 に対し商工省より工業奖励金を交付されて，40 $\mathrm{m}^{\mathrm{s}} / \mathrm{h}$ 複 精留式酸素分離装置を完成した。また昭和 9 年より海軍 艦政本部の命を受けて艦載用 $15 \mathrm{~m}^{\mathrm{s}} / \mathrm{h}, 30 \mathrm{~m}^{3} / \mathrm{h}$ 複精留式 酸素分離装置の製作を開始し，終戦までに駆逐艦用(15 $\left.\mathrm{m}^{\mathrm{s}} / \mathrm{h}\right) 49$ 基，巡洋艦用 $\left(30 \mathrm{~m}^{\mathrm{s}} / \mathrm{h}\right) 82$ 基を製作した。こ れらは日本海軍が世界に誇った酸素魚雷用として使われ たすのである。昭和 18年より海軍航空基地用として, 車 載式 $5 \mathrm{~m}^{8} / \mathrm{h}$ 酸素分離装置の製作を開始し終戦までに 55 基を完成した。このほか造船用として $100 \mathrm{~m}^{3} / \mathrm{h}$ 酸素分離 装置 41 基を製作した。終戦までに同社は各種約 300 基 の空気分離装置を製作した。

神戸製鋼は昭和 9 年車載式液酸 $5 l / \mathrm{h}$ の複精留式分離 装置の製作に成功し, 昭和 11 年に海軍然料廠の指尊に より日本窒素 (阿吾地) の石炭夜化用いるリンデ・フ レンクル式 $2,000 \mathrm{~m}^{3} / \mathrm{h}\left(98 \% \mathrm{O}_{2}\right)$ 酸素分離装置 2 基の製 作を開始した。これは当時として極めて野心的な試みで, 当事者は随分苦心されたようである。同社は終戦までに 大小合わせて 28 基の空気分離装置を完成した。

また三菱化工機は昭和 11 年, 帝国酸素は昭和 18 年空 気分離装置の製作を開始した。湘南製作所は戦時中陸軍 に協力して $60 \mathrm{~m}^{3} / \mathrm{h}$ 程度の酸素分離装置の製作を開始し たが終戦とともに空気分離装盤製作工場を閉鎖した。

\section{$1 \cdot 2$ 昭和 20 年以後}

1.2.1 復期興（昭和 20〜25 年）終戦になると世 を挙げて食料增産の時代となった。そのため, 終戦によ り遊休施設になっていた酸素分離装置をアンモニア合成 用の窒素分離装置に改造することが行なわれ，さらに窒 素分離装置の新設が行なわれた。

たと党ば，神戸製鋼は $1,000 \mathrm{~m}^{8} / \mathrm{h}$ 窒素分離装置 4 基, $1,200 \sim 3,000 \mathrm{~m}^{3} / \mathrm{h}$ 酸素分離装置 4 基を製作し，日本理 化す戦争中各造船所用として製作した $100 \mathrm{~m}^{3} / \mathrm{h}$ 酸素分離 装置 15 基を $400 \mathrm{~m}^{3} / \mathrm{h}$ 空素分離装置飞改造するほか, 1,000 $\mathrm{m}^{8} / \mathrm{h}$ 窒素分離装置 4 基を制作した。また三菱化工機 む $1,000 \mathrm{~m}^{8} / \mathrm{h}$ 室素分離装置数基を肥料工場へ納入した。

$1 \cdot 2 \cdot 2$ 大型空気分離装直 前述のよ5にリンデ・フ レンクル式大型酸素分離装置は戦時中から神戸製鋼にて 数基製作されたが，本格的製作されるよ5になったの は，終戦後である。この当時のリンデ・フレンクル式酸 素分離装置の特徵は, 空気中の炭酸ガスと水分を除去す

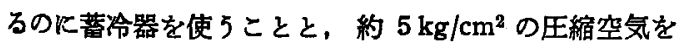
大気圧まで膨張するのに衝動式膨張タービンを使用した ことである。このタービンの効率は約 $65 \%$ で，これの みでは寒冷発生量が不足であるため, 処理空気量の約 5 \%を高压に圧縮して寒冷の発生を補なっている。
終戦から昭和 28 年までた 製作された神戸製鋼の $O F$ 型 8 基, 日本理化の HNR 型, MNR 型各 1 基はいずれ もこの型式である。

ところでッ連のカピッッアは昭和 14 年に反動式膨張 タービンを用いて約 $5 \mathrm{~kg} / \mathrm{cm}^{2}$ の空気を大気圧に膨張す る際約 85\% の効率を発揮することができ，全低圧式空 気液化装贯飞成功した。

この文献を終戦後, 科学研究所が入手し, 同所の仁科 ・大山両研究室が反動タービンの研究に着手し, 日本理 化もこれに協力して, カピツッア式空気液化装置の研究 をなし，さらに全低圧式酸素分離装置の試作研究を完成 した。昭和 27 年科学研究所は八幡製鉄より $500 \mathrm{~m}^{\mathrm{s}} / \mathrm{h}$ 低 圧式酸素分離装置の注交を受け，三菱化工機と日立がこ れに協力して，この装置を製作した。つぎにこの型式の 装置は昭和 30 年以後日立製作所によってTO型または TON 型として製作されている。

また神戸製鋼，日本理化も全低圧式空気分離装置を製 作して拉り, 昭和 31 年以降の大型装直は低圧式が多い。

これら大型酸素製造装直は化学工業用は勿論, 昭和 25 年頃から始まった酸素製鋼で平炉および転炬に酸素を 吹き込むよ5になり, 需用が急に多くなり, 容量も最高 $10,000 \mathrm{~m}^{3} / \mathrm{h}$ 酸素と超大型出現し, さらに多量の高純 度窒素も同時に採取するなど，その技術は向上した。

昭和 21 35 年までに製作された，これら大型空気分 離装置は, 神戸製鋼 28 基, 日本理化 16 基, 日立製作所 30基, 三菱化工機 1 基, 合計 75 基に達している。

1.2 .3 液体酸素製造装置この数年間,製鋼その外 の工業にたいする酸素の需用はいちじるしく增大し，今 までの規模の酸素工場では応じられなくなり，昭和27年 帝国酸素が自家用液酸装置を尼崎飞据付け, 日本理化す 昭和 29 年以来, 液酸装固を製作している。

昭和 27〜35 年に製作された液酸装直は, 容量が酸素 ガス換算 $500 \sim 1,500 \mathrm{~m}^{3} / \mathrm{h}$ で, 帝国酸素 7 基, 日本理化 13基, 神戸製鋼 1 基である。この液酸装置の中にはアル ゴン製造装置を付属するすのが多い。

なお輸入液酸装置としてはリンデ社,メッサー社, エ アプロダクト社から各一基輸入されているが，これは高 純度アルゴン製造装置として輸入許可されたるのである。

\section{2. ガス分離装量}

このガス分離装置には低温を利用してコークス炬ガス などからアンモニア合成用水素・窒素混合ガスを分離す る装置, 高純水素を分離する装置, ならびにメタン，エ チレンなどを分離する装置を含む。”

大正12年東洋高圧（颜島）にてアンモニア合成を始め て以来，昭和15年までアンモニア合成用ガス分離装置は 
いずれひレール・リキド社やリンデ社から輸入していた。

\section{$2 \cdot 1$ 昭和 20 年まて}

しかし昭和10年頃より海軍然料廠（徳山）の指尊にて 石炭液化が国策として採り上げられ，石炭液化用高純水

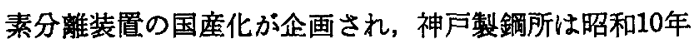
海軍然料廠 (徳山) V $800 \mathrm{~m}^{8} / \mathrm{h}$ 水素分離装置を試作し, 昭和 $11 \sim 17$ 年に $2,500 \sim 3,000 \mathrm{~m}^{3} / \mathrm{h}$ の大型装置 10 基を 海軍然料潡 (徳山, 四日市), 陸軍然料廠へ納入した。ま た日本理化も昭和 16 17 年に 4,500 $\mathrm{m}^{3} / \mathrm{h}$ 水素分離装置 4 基を東邦化学と海軍然料廠（四日市）へ納入した。

この場合，神戸製鋼の型式は膨張機によって $-200^{\circ} \mathrm{C}$ の低温を発生するクロード方式であり，日本理化の型式 は約 $10 \mathrm{~kg} / \mathrm{cm}^{2}$ の原料ガスを, 减王した液体窒素により $-210^{\circ} \mathrm{C}$ 程度に冷却して約 $98 \%$ の精製水素を得るリン デ方式であった。

この時代にェチレン，プロパンなどの炭化水素分離装 㯰が，やはり神戸製鋼と日本理化の両社で数基製作され て海軍然料廠へ納入され，四ェチル鉛の製造などに用い られた。

\section{$2 \cdot 2$ 昭和 20 年以後}

終戦後は荒廃したアンモニア合成用ガス分離装置の復 睅が行なわれ，さらに昭和 $25 〜 30$ 年に新規装置が三菱
化工機，帝国酸素各 1 基，神戸製鋼 2 基が製作された。 特に最近は安価な水素を得るため，水素源を石炭より 重油あるいは天然ガスにはとんど転換した。この場合， 原料を酸素により部分酸化して水素原料ガスを得，これ を精製してアンモニア合成用ガスを製造するのに都合の よい装置として，低王式空気分離装置とガス分離装置と を一体化した「空気分離・ガス分離結合装置」がアメリ カやドイッで試みられた。昭和 33 年以降わが国です， この結合装置が日立製作所 3 基, 神戸製鋼 1 基が製作さ れ，アンモニア工場に納入された。

\section{むすひ}

以上ガス分離装置の国産化の初期から昭和 35 年まて の大様を述べた。この間各社の払った努力には淚ぐまし いものがある。そして各メーカーは現在，国内はるよ り，海外へす装盾および技術の輸出を行ないつつある状 態である。

終りに臨み，本文を作成するに当り，貴重な資料を提 供された各社に感謝するととすに，古い記憶で書いた個 所む多く，正鴻を得ない点す多々あると思うが，文責は 筆者にあることをお詑びする次第である。
各メ一力新規媻作装置

\begin{tabular}{|c|c|c|c|c|c|c|}
\hline 昭 和 & 西 曆 & & $x$ & $t$ & & \\
\hline 9 年 & 1934年 & 日 & 本 & 酸 & 素 & \\
\hline$"$ & $" 1$ & 日 & 本 & 酸 & 素 & \\
\hline 10年 & 1935年 & 神 & 戸 & 製 & 鋼 & \\
\hline 11年 & 1936年 & 三 & 菱 1 & 七 I & 機 & \\
\hline$" \prime$ & $" \prime$ & 神 & 戸 & 製 & 鎆 & \\
\hline 13年 & 1938年 & 神 & 戸 & 製 & 鋼 & \\
\hline 16年 & 1941年 & 日 & 本 & 理 & 化 ${ }^{1)}$ & \\
\hline " & "I & 日 & 本 & 理 & 化 & \\
\hline$" 1$ & $\prime \prime$ & 神 & 戸 & 製 & 鋼 & \\
\hline 18年 & 1943年 & 日 & 本 & 理 & 化 & \\
\hline$"$ & " & 帝 & 国 & 酸 & 素 & \\
\hline 20年 & 1945年 & & & & & \\
\hline 22年 & 1947年 & & 咞（E & 日本理 & 化） & \\
\hline 25年 & 1950年 & 神 & 戸 & 製 & 鋼 & \\
\hline$" \prime$ & $"$ & 日 & 本 & 理 & 化 & \\
\hline -27年 & 1952年 & 科 & 研 (三 & 三菱化 & 工工機, & 日立） \\
\hline " & $" \prime$ & 日 & 本 & 理 & 化 & \\
\hline " & $" \prime$ & 帝 & 国 & 酸 & 素 & ' \\
\hline$" \prime$ & $\prime \prime$ & 神 & 戸 & 製 & 鋼 & \\
\hline 29年 & 1954年 & 日 & 本 & 理 & 化 & \\
\hline 30年 & 1955年 & 日 & 立 & 作 & 所 & \\
\hline$" \prime$ & $" \prime$ & 日 & 立 量 & 作 & 所 & \\
\hline$\prime \prime$ & $" \prime$ & 帝 & 国 & 酸 & 素 & \\
\hline 32年 & 1957年 & 日 & 本 & 理 & 化 & \\
\hline$\prime \prime$ & $" 1$ & 帝 & 国 & 酸 & 素 & \\
\hline
\end{tabular}

新規装置・能力 $40 \mathrm{~m}^{3} / \mathrm{h}$ 酸素（䙓精留式） $15 \mathrm{~m}^{3} / \mathrm{h}, 30 \mathrm{~m}^{3} / \mathrm{h}$ 酸素(艦载型) $5 l / \mathrm{h}$ 液体空気

(製作開始)

$2,000 \mathrm{~m}^{8} / \mathrm{h}$ 酸素 (OF型)

$1,220 \mathrm{~m}^{3} / \mathrm{h}$ プロパン

$100 \mathrm{~m}^{8} / \mathrm{h}$ エチレン

$4,500 \mathrm{~m}^{8} / \mathrm{h}$ 水素（リンデ式）

$4,500 \mathrm{~m}^{3} / \mathrm{h}$ 水素（クロード式）

$5 \mathrm{~m}^{8} / \mathrm{h}$ 酸素(車戴式)

(彆作開始)

終

カピッッフ式

$2,000 \mathrm{~m}^{8} / \mathrm{h}$ 酸素

プロパン

$500 \mathrm{~m}^{\mathrm{s}} / \mathrm{h}$ 酸素（全低圧式）

$2,000 \mathrm{~m}^{3} / \mathrm{h}$ 酸素 (HNR 型)

$450 \mathrm{~m}^{3} / \mathrm{h}$ 液体酸菜

$3,600 \mathrm{~m}^{8} / \mathrm{h} \mathrm{NH} \mathrm{NH}_{3}$ 合成廃 ガス

$500 \mathrm{~m}^{8} / \mathrm{h}$ 液体酸素

$2,200 \mathrm{~m}^{3} / \mathrm{h}$ 酸索 (TON型)

$1,500 \mathrm{~m}^{9} / \mathrm{h}$ 酸素 (TO 型)

$3,600 \mathrm{~m}^{3} / \mathrm{h} \mathrm{NH}$ 合成ガス

$3,000 \mathrm{~m}^{3} / \mathrm{h}$ 酸素 (NR 型)

$2,800 \mathrm{~m}^{3} / \mathrm{h}$ 酸素
設 置 場 所

日本酸素(郡山)

駆逐艦，巡洋艦

海軍燃料廠（徳山）

日本窒素(阿吾地)

海軍然料廠（徳山）

海軍燃料廠（德山）

東 邦 化 学

四日市海軍燃料廠

海軍牟空基地

科学研究所

神戸製鋼

昭 和 石 油

八幡彆鉄（八幡）

川崎裴鉄（草合）

帝国酸素（尼崎）

東洋高压（砂川）

日本酸素（川崎）

協和醇醉

别府化学

新日本窒素（水俣）

住友化学 (新居浜)

日本カーパトド 


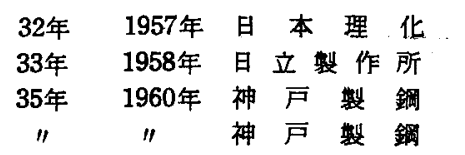

1) 昭和13年日本醇絭は日本理化と社名变更
$3,600 \mathrm{~m}^{3} / \mathrm{h}$ 炭鋌ガス
$11,000 \mathrm{~m}^{8} / \mathrm{h}$ 結合装㯰
$18,000 \mathrm{~m}^{2} / \mathrm{h}$ 結合装置
$1,500 \mathrm{~m}^{3} / \mathrm{h}$ 液体酸素

三菱鉱業 (大夕張)
別府 化 学
宇 部 興 産
大 阪 酸 素

\section{集 擮 装 量*}

\section{橋 本 清 隆**}

化学プラントにおいて集塵は重要な単位操作の1つで あることは論を俟たない。しかし集塵の対象となる煙蓩 体の性質と状態はまことに不定常であって, 電気機械, 空気機械, 水力機械などによって报われる対象物質とは まったく異るところに集痤現象あるいは集塺装置の取り 扱いのむずかしさがある。集塵に関する研究が 1 世紀半 に亘る今日な和多くの研究の余地を残していることはあ ながち研究に费わる者の急慢ではなくむしろ研究対象の 幅の広さに理由を見出だすべきすのであろら。ここに化 学工学協会創立 25 周年を記念隹塵装置発達の跡を顧 みることは意義あることと思 5。

集瑟装置の利用範囲は，極めて広範囲に亘っておりそ の利用目的も，

（1）疾病，污染，濃霧などの公害の防止

(2) 磨蝕, 閉塞, 腐蝕など設備の機能障害の防止あ るいは熱効率または生産効率の向上

（3）職場衛生環境の改善による労㗢能率の增進

（4）製品の品質または精度の向上あるいは商品, 考 古品などの価値の保存

（5）排ガス中の有価物の回収またはガスの清浄

（6）製品の分級選別あるいは捕集

など様々である。したがってその要求される集塵率も施 設目的と企業的経済性とによって様々であり, 設備規模 にいたっては, 今日では, 小は計測器保護あるいは試験 研究用の処理ガス容量数 $l / \mathrm{h}$ から大は $1000,000 \mathrm{~m}^{3} / \mathrm{h}$ 余 りの広範囲におよんでいる。これらの装置で取り扱われ る煌霜の性留はその発生源によって，分散相の粒子径 范 $10^{-6} \mathrm{~cm}$ 以下ないし $10^{-1} \mathrm{~cm}$ に亘り, 電気抵抗火拉 いては $10^{\circ}$ 以下から $10^{14} \Omega-\mathrm{cm}$ 以上の相違がありその 成分組成も極めて多様である。煙霞の状態についてみる と, 温度に打いて需度以下から $600^{\circ} \mathrm{C}$ 以上, 気压に招い て $700 \mathrm{mmHg}$ から $30 \mathrm{atg}$ 以上, 乾燥粉体から液状物, 含㾝量では $1 \mathrm{mg} / \mathrm{m}^{3}$ 以下から数 $100 \mathrm{~g} / \mathrm{m}^{3}$ 以上のものが

* 昭和 36 年 6 月 7 日受理

* （株）日立製作所 日立研究所
ある。かような広範囲な性質，状態，規模の煙霧を上述 のよらな諸種の目的にしたがって経済的に処理する集麼 装置の種類，形式もまた多種多様であってそれぞれの特 徵あるいはその組み合わせが合理的に用いられている。

集麼を対象煙霧体とその集堅に関する研究がなされ 始めたのは 1800 年頃からのようで，その発展の経過を 緾めれば別表の上うになる。

すなわち諸工業の発展にともない煙害問題が重要な課 題となり煙霧の性質動静とその測定に関する研究がとり あげられ諸種の集麼装置が開発された。これらの集歴技 術はまた, 化学工業に批いてガス清浄, 粉塵処理など諸工 程の効率向上と企業の合理化に重要な役割をなすことが 知られ，集麇機構と集塵効果の測定表示に関する研究が 進められた。あるいはその組み合わせ用法などが開発さ れその用途がますます拡げられるに打よんで dust control に関する資料の增補, 測定法の標準化なと基本技術 としての体形づけがなされるにいたった。

これらの研究から操業条件汪ともな5㖶蓩の性質状態 ならびにその処理目的と，集塵装置選定の基本的考方方 が明らかになったが, 総じて当集麼効果を得る所要経費 は近似といえる。

近年特に目覚ましい進歩発展をなしつつある化学工業 における集麼装置の処遇についてみると，

（1）炭化水素類の減圧熱分解 $(-700 \sim-450 \mathrm{~mm}$ $\mathrm{Hg}, 50 \sim 80^{\circ} \mathrm{C}$, 主ガス成分 $\mathrm{H}_{2}, \mathrm{CO}, \mathrm{C}_{2} \mathrm{H}_{2}$ など)

（2） 油類の高压熱分解 $\left(28 \sim 33 \mathrm{atg}, 170 \sim 200^{\circ} \mathrm{C}\right.$, ガ ス主成分 $\mathrm{H}_{2}, \mathrm{CO}$ など)

（3）油類または石炭の直接ガス化(400〜600 mmAq, $30^{\circ} \mathrm{C}$ ，ガス主成分 $\mathrm{CO}, \mathrm{H}_{2}$ など）

などによる合成原料ガス製造では分解ガス中の遊離 ca-

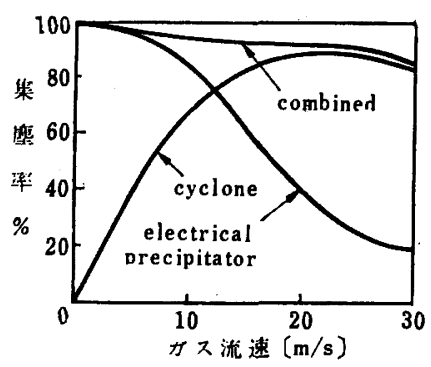

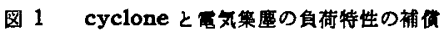




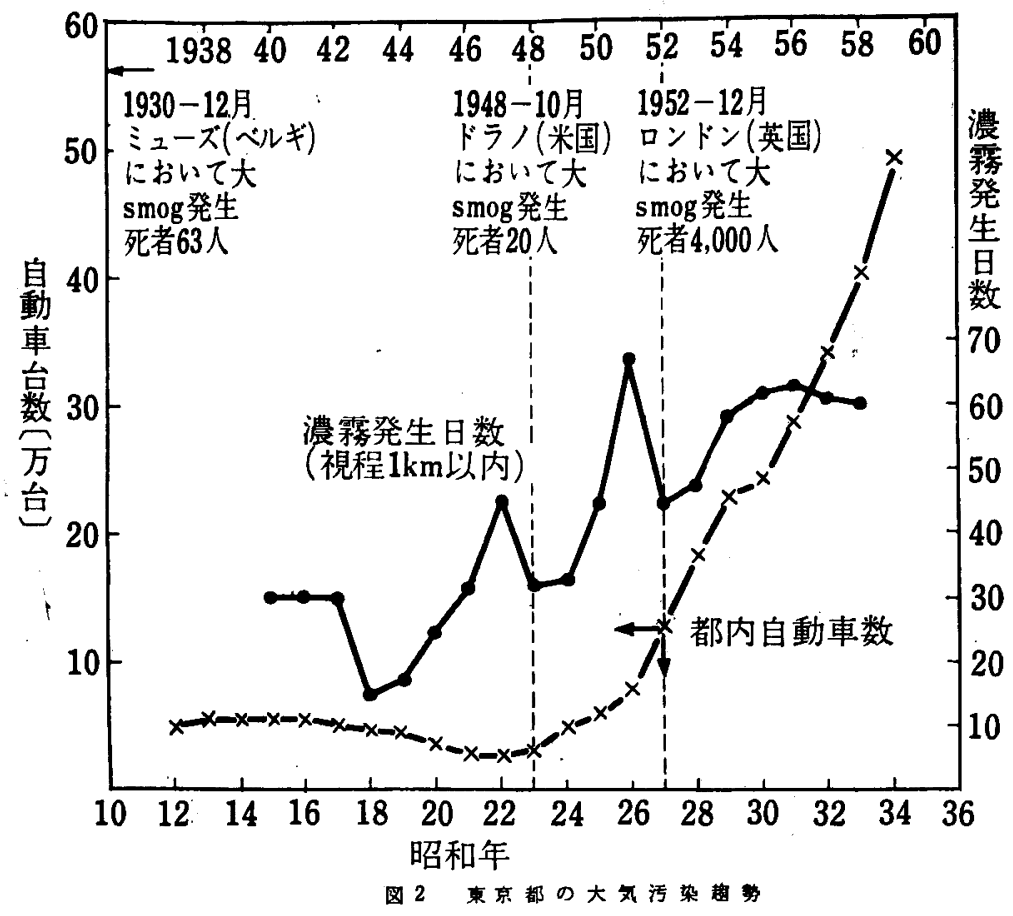

rbon black の除去精製に用いられた filter は保守困難 であったが，湿式電気集鹿の応用によっていずれる满足 な操業改善が得られる。硫酸, 燐など熔鉱あるいは電炉 熔鉱による原料ガス製造, あるいは,セメント,アルミナ などの焼成排ガスの集塵では cyclone と電気集歴の特徽 の組み合わせで優れた効果を収めている。すなわちこの 組み合わせは低負荷に扰ける cyclone の欠点と高負荷に おける電気集痤の欠点とを相補 5 ので(図1)負荷変動幅 が大きいか, あるいは始動停止を反復する性質の plant には特に有効である。しかし分級にはcyclone または静 電界が有效であって電気集痤は適さない。その他 $\mathrm{Cr}, \mathrm{Zn}$, $\mathrm{Pb}$ などの製鍊工程に和けるガス中の金属または酸化金 属 fume あるいは carbon black 製造の排ガス中の carbon は元来掩蔽能力が 大で 煙害が甚しいものである。 しかしこれらの排ガス処理においては電気集塵は煙霧の 高電気抵抗あるいは荷電回路の電気絶縁保持の困難など で実用が跗躇され，また湿式集塵は污水処理に困難があ ク, bag filter では保守困難の故で対策が見送られてき たものであるが，公害防止気運の高まりでついに電気集 塵による解決の途が研究達成され公害防止と生産原単位 低滅との 1 石 2 鳥の効果をるたらすにいたった。
T. O. Plant（全低圧式酸素分離装置)の発達にともな い酸素製鋼の効率が急速に向上した反面においては、こ の排㖶による煙害が一層甚しくなったが，これる電気集 痤あるいはこれと venturi scrubber, 湿式 cyclone など との併用によって解決が与えられた。ロンドンに乱いて は, 1952 年 12 月に三たび大 smog 災害が起こり，4,000 人の死者を出しており，また東京都の統計です図 2 のよ 5 に濃務日数の增勢を示している折柄，公害問題の代表 的対象とされた電炉製鍊, セメント製造, 発電, 酸素製 鋼, または粉釷焼結, carbon black 製造などの白, 赤, 黒各種の排煙ならびそ諸化学工業の排気の煙害が，集黍 技術の進歩普及によって逐次解消されていることは諸工 業の発展を促するのとして，喜ばしい次第である。

しかしなからら，一般化学工業に批いてはるとより，そ の他の製粉, 莤陶業, エ゙ム加工業など中小工業の排湮処 理および環境改善あるいは作業能率の増進, ジミ焼の煙 の処理など，集糜技術の適用を必要とする面がな敃幾多 残されており、これらに手軽に採用される集歴器の研究 開発ならびに生産合理化と公害対策に有効な管理行政の 運用が期待される。 


\begin{tabular}{|c|c|c|}
\hline 年次 & 宪 経 過 & 国外での研究経 過 \\
\hline 1824 & & 電気集塵現象発見 \\
\hline 1870 & & dust \& disease 問題起る \\
\hline 1883 & & 熱集塵現象の研究 \\
\hline $\begin{array}{l}1884 \sim \\
1908\end{array}$ & & 化学工場に電気集塵実施, 煙粒子荷電現象の研究 \\
\hline 1915 & 製錬所の鉣害防止に電気集塵器を輸入 & 次元解析法, Tyndall 光による粒度測定 \\
\hline 1917 & 煙粒子帯電理論 & \\
\hline 1919 & & 電気集塵効率の実験 \\
\hline 1920 & & 粒径分布測定の研究 \\
\hline 1921 & 電気染装現象発見 & 粉塵の比表面樍測定 \\
\hline 1922 & & 電気集塵効率理論式 \\
\hline 1923 & & 煙霧体に関する総合報告, 分散粒子径の測定 \\
\hline 1924 & 電気集麇器の生産始む & 溦粒子工学の体系つけ \\
\hline 1925 & 九大に研究用電気集蛋器 & 都市煙雾の研究 \\
\hline 1926 & セメント工業に電気集塵 & \\
\hline 1927 & 電気集糜現象の研究, 硫酸ガス清浄に電気集魔 & 㑌爆の研究 ・・ \\
\hline 1929 & & 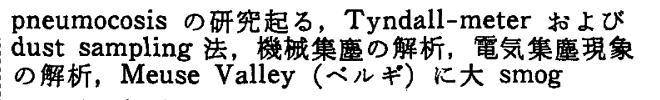 \\
\hline 1930 & 電気集塵の綜合報告 & 含歴量記録計 \\
\hline 1932 & 電気集塵の空間電荷現象および逆電麈現象 & cyclone 現象の解析 \\
\hline 1933 & Cottrell の特許権満期 & asbestoscosis, dust と保健の総括発表 \\
\hline 1934 & $\begin{array}{l}\text { pulp 蒸解液か } 5 \text { soda 回収に電気集塵, 溦粉末測定 } \\
\text { 法, boiler } に \text { 電気集塵 }\end{array}$ & 渦流域での蒸発現象研究 \\
\hline 1935 & $\begin{array}{l}\text { 硫酸, 製鉄, タール,フルミナ，製錬など各種工業に } \\
\text { 電気集塵が普及 }\end{array}$ & $\begin{array}{l}\text { 電気集鹿器内現象の研究, 汇過集塵の研究, 新形 } \\
\text { cyclone : VanTongeren }\end{array}$ \\
\hline 1936 & $\begin{array}{l}\text { 高炉ガス清浄に Theisen 集麇機, 粉体比表面積測定 } \\
\text { 法, } \mathrm{Cr}, \mathrm{Au}, \mathrm{Ag} \text { 製鍊に電気集塵 }\end{array}$ & $\begin{array}{l}\text { 都市空気污染調査, impinger 集塺の研究, 工業煙霧 } \\
\text { の研, 音波集塵の研究 }\end{array}$ \\
\hline 1937 & 鹿苏処理煙害防止に半湿式電気集塵 & 2 stage 電気集塵器, cyclone の器内現象と性能の解析 \\
\hline
\end{tabular}

1939 電気染気清浄器, 光電管式粒度測定法, 低圧ガス中の 計数法煙霧濃度表示の研究, 電気集麼現象の研究進む, 電気集歴現象と適用限界の研究, bauxite, 銅転炉, 塩 電気集鹿器の改良研究, 静電選別

酸, $\mathrm{CH}_{4}$ 電张分解ガス清浄などに電気集塵

1940 粒度湘定法の研究進む，湿式電気集塵の研究，都市煤

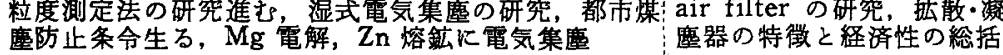

1941 セメント篩器試験基準, 電炬 fume の電気集魔と電気集塵法を塗装に実用, Dust Sampling Apparatus gas conditioning 効果, 集魔率測定法, 静電選別々 Test Code : A.S.M.E., 製鋼 fume $の$ venturi 集麼 分級

1942 cyclone 性能諭, $\mathrm{Hg}$, As などの蒸気製錬 carbon に怙ける mist 面への微粒子拡散効率

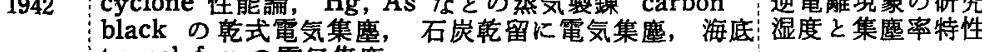
逆電離現象の研究, 合成触媒 dust などの抵抗一温度一 tunnel fog の電気集塵

1945

1946 電気塗装を実用化

1947 高温域の電気集蝔現象

1948 Starclone の実用化, 下吹 Antony 形 scrubber, Cascade venturi

1949 湿式電気汇菌法, 静電 emulsion 分離

音波集塵の工業化実験

透過法比表面積測定

Donora（米）に大 smog 発生, Micromeritics とま る

渦流中の払散集塵理論, Chem. Engrs' Handbook の 增補

1950

cyclone 設計法, turbidimeter の研究, 湿式䉓気汇菌 装置の研究

1952 venturi 性能論, cyclone能解析, 半湿 scrubber : Air Tumbler, 触媒 Se 回収に湿式電気集塵

1953 標準節目の検討, 粉末沈降分析法, Winker gas 清浄 飞湿式電気集鹿, Thylox gas 清浄に湿式電気集塵, ber の研究, 機械集塵装惪の研究総括, fly ash 分級; 降分析, 俘遊粉麼の測定法の研究, cyclone scrubber 装置，汇過集鹿特性の研究 cycloneの相似則，音波集

塺, 薏心電気集鹰, dust control 研究会, fly ash 選択集塺装置 器特性, 各種集塵器の現場実験, cyclone 技術の総括, 逆吹 bag filter, 環境衛生湘定法, Pea-body scrub- V.D.I., 粒度表示式線図 : Rosin-Rammler, 光電式沈

煙蓩の湿度と fume 集蝔率, London に大 smog 発 生,粒度々比表面積, 平炉 dust control における集塵 器性能比較 節分試験規格 : British Standard, dust の粒径と集鹿 dust sampling, 粉体技術委員会, 音波によるtarの集麼，比表面積計算法, 顕鏡徽と光電池による自動粒度測定 


\section{沈降分離・水処理装置}

I. 沈降分離装置*

沈降分離操作は多くの工業とはきり離すことのできな い単位操作の一つで，これに適合する装置も古くから数 多く使用されてきているが, 沈降分離装置を発展的に眺 めることはむずかしいため，ここではその発展的流れを まとめるだけにとどめる。

\section{1. 回分式沈降樯}

重力による沈降分離操作は怙そらく紀元前における飲 料水の清澄に始まるであろらが，これを装置としてみる ならば（図1）のよ5な長方形の回分式沈降慒があげら れる。

操作の方法は，はじめに処理泥しょ5を充満し一定時 間放置した後上澄液をサオフオンなどで抜き，ついで濃 縮泥しょらを栓から，あるいはシャべルなどで取り出し て一行程が終了する。この方法は非能率的ではあるが， 小規模操業の場合装置設計が簡単で，しかる操作の単純 性から現在も使用されている。

\section{2. アレンコーンおよびカローコーン}

しかし規模が拡大し，沈降分離操作に連続性が要求さ れるようになってア、レンコーンおよびカローコーンが考 えだされた。これはいずれも機械的集泥槓を持たない連 続沈降分離装置で, 慒底部が $45^{\circ} \sim 60^{\circ}$ 飞急傾斜している ものである。給泥は上部中央にある給泥口から槽に入り， 溢流は連続的に槽周壁の溢流桶から取り出される。排泥

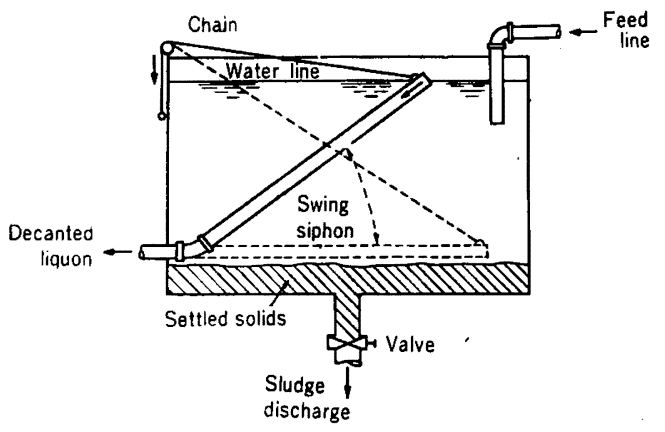

図1回分式斺槽

- 昭和 36 年 6 月 27 日受理

** 三機工粦 (株)

取り出しはアレンコーンの場合槽内のフロートによって 連動される排泥口のパルプにより，カローコーンと批い てはグーズネックサイフオンによって行なわれる。

\section{3. 連紩シックナ}

アレーコーン打よびカローヌーンは初期の回分式沈股 槽に比すればかなり優れているわけであるが，必ずしる 满足すべきすのではない。すなわち，i）一定浱度の一粎 な排泥を得難い。ii）固体はコーンの壁に沈殿し、これ が脱落してスピゴットを閉塞する。iii) コーンの径に比 例して高さが增大することは，経費あるいは建設の面で 制限される(せいぜい径が $3 \mathrm{~m}$ までが経済的である)。 iv）小さいコーンを多数ならべ，同時に操業することは 非常にむずかしい,などの本質的な問題が残る。

一方, コーンのよ5に必ずしも径に比例して高くする 必要のないことが泥鉱の処理で経験されていた。また 1904年には連続クラシファイヤが成功している。このよ 5 な背景の下に 1906 年 Dr. J. V.N. Dorr が連続䡙維 (continuous thickening) の考え方を取り入れて, Mogul Mining Co.の 300 ton mill における泥鉣処理に機械的 集泥䫅，慒周壁に溢流觕，給泥溜め括よび排泥錐などを 備えた $11 \mathrm{~m} \times 4 \mathrm{~m}$ 円形連続シックナすなわち、ドル・シ ックナを完成した（図 2 参照）。

その後, 銅, 鉛, 亜鉛, 錫などの冾金方面あるいは噒 酸塩の 洗潇, 下水処理部門などにも適用分野が広げら れ，1909年にはコーンに代ってほとんど連続シックナか 使用されるにいたった。また 1930 年にはシックナの径 は $70 \mathrm{~m}$ にもおよんでいる。

それ以来今日まで連続シックナの根本的な変革はない が，処理的濁液の多種多様化に対応して合目的々な種々 の沈降分離装置が設計製作されてきた。次にそれらを目 的別に大別してみる。

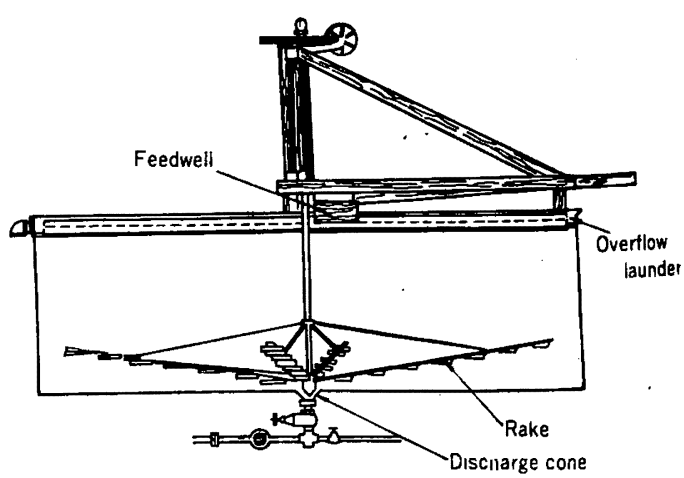

因 2 最初のドル・ショクナ (1906 年 Dr.J.V.N. Dorr Kより 明され，南ダヌタ・ブルーマ所在 Mogul Mining Co. K拧 いて使用した 
i）排泥濃度を高める デンススラッジ・シックナ 招るに污泥処理に適用されるすので, 濃厚排泥を得るこ とを目的として集泥槙に垂直な杭の棚を多数備えたすの である。

ii）大荷重のための集泥機構 トラクションおよびト ルク・シックナ 化学工業の発展あるいは廃水処理の 問題は，泥しょ5の大量処理に向い大容量のシックナが 要望され集泥梖に対しても大負荷に対処するすのが必要 となり，中心柱型でしかも自動安全装置を備えたものが 製作されてきた。現在では径が $100 \mathrm{~m}$ にもおよび,トル ク容量も $13 \times 10^{6} \mathrm{Kg} \cdot \mathrm{m}$ にいたっている。

iii）敖地面積の制限 トレイ・シックナ 限定され た教地面積に対して大きな沈降面積を必要とする場合単 段シックナの重ねた形のトレイ・シックナが適用される 様になった。またこれは諸設㣁費が少ないことあるいは 熱損失の少ない点からす考虑されるものである。

iv）兰の他 邪魔板插入型シックナ 沈降慒の有効 沈降面積を增大するすので, 分散状の稀薄愁濁液から清 澄液を得る場合に主に適用される。

v）流清澄度を高める 連続クラリフフイヤ 連 続クラリファイヤは用水処理あるいは下水処理部門など において，比較的俙薄な懸濁液を処理するため多くの 工夫をされている。そのおもなものとしては給泥溜め (feedwell) 溢流槲 (overflow launder), 浮㳯除去装置 (skimmer)，などである。給泥溜めについては近年凝集 奻果を上げ，かつ沈降槽の滞留効率を增大するドル型給 泥溜めが発表されている。

\section{4. 強制凝集沈殿装置}

最近特に産業廃水処理あるいはその他の凝集性慜濁液 の処理に適用されてきている種々の垂直流型沈殿装置, すなわち強制凝集沈即装置はいずれる粒子を凝集せしめ ることを目的として特殊な考應をはらったものである が, その後は連続シックナと同様な機構で処理するるの である。装置としてはアクセレータ，スポールディング プレシピテータ，ハイドロトリータなどが挙げられる。

\section{表 1 沈降分離装置の主要適用分野}

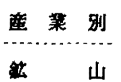

制造工乘

用䇹水処理

$$
\text { 主な通用分 野 }
$$

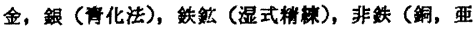

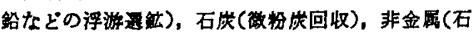
死石，㩲鉱石）など

セメント(湿式)，染料颜料，赀紙，アルミニウム， 烸酸肥料，精㸵，海水からのマグネシウム回収，ソ 一ダエ菜など

用水処理，慗铁临式廃ガス処理，あるいは製紙，会 品, 碩料，廃水などの愁拄処理など

\section{むすび}

沈降分離装置の変せんについて，回分式の沈降慒から 連続シックナへの推移, ならびにその後の発展的方向々 して処理物の多種多様に対応した連続シックナの種々の 設計改良を簡単に述べた。なお゙，表１に国内における沈 降分離装直のおもな産業別適用分野を示す。

II. 水処理装置*

\section{山 羽 真士夫***}

\section{1. 戦前の水処理装算}

用水処理は，上匆道，工場用水とも古来の機械設備を しない単純沈殿, 緩速沪過, 塩素隇菌の方式が行なわれ ていたが，日本では明治 20 年横浜市水道が水処理を行 なった最初である。急速汇過装固は大設備は少なかった が，輸入装置もあり，その洗淮方式は空気覮拌と逆流洗 滌と併用したものもあった。

下水道む明治時代より実施されてきた。方式はスクリ 一ン, 沈砂; 最初沈殿, 活性污泥, 撒水汇床などの生物 化学処理, 最後沈殿などの組み合わせである。廃水処理 はレーヨン工場，製紙パルプ工場，化学工場などで，曝 気中和, 沈殿などの処理, 生物化学的処理も数例行なわ れていた。

軟化処理は，天然ゼオライトを使用した処理，過マン ガン酸カリで処理したマンガン・ゼオライトを使用する 脱鉄, 脱マンガン処理が小規模に行なわれていたが，大 量の処理は実施されていない。

\section{2. 戦後の水処理装置}

用水処理 水中の浮迶物による濁質を明ばんを加えて 凝集沈殿により清澄化することは可成り古く中国で行な われていたことであるが，大量の用水処理でこれを行な 5 には，以前は池に迂回して原水を流し，部分的にせき 板をおいて流速に緩急を生じさせ，水流筧䢁によってフ ロキェレーションを行なわさせて沈殿池に導いた。沈殿 池も水を清澄化させるが, 沈殿物は底部に堆積させたま ま, 数ヶ月に一度通水をとめて, ポンプ, 人力などによ り排出していた。用水処理の処理量が急激に莫大になっ てきて, 処理の効果を増大させ人力を節約させるため,こ れらの処理設備に機械を使用し，さらに近年それらの機 械設備の自動運転化が急速に発展した。

薬品急速混和にフラッシュミキサ（急速覞挥）, 凝集

* 昭和 31 年 6 月 27 日妥理

** (标) 佂原インフィルュ 


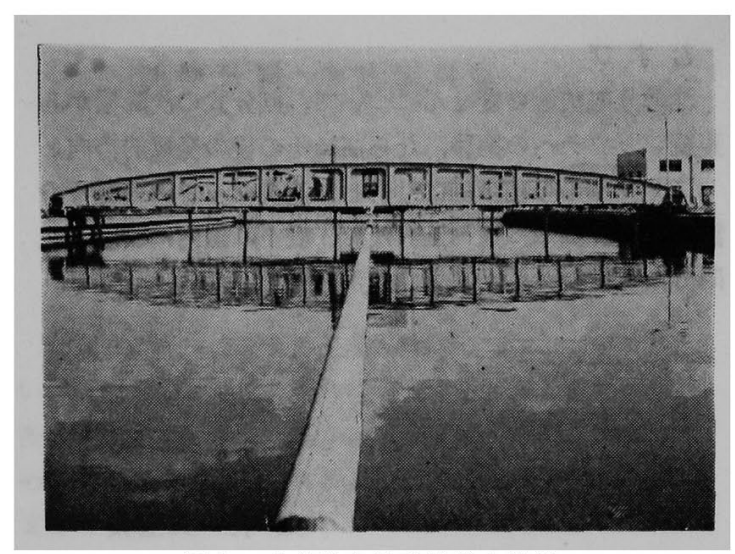

图 1 全自動走行式㩧等せ装置

にフロキュレータ（緩速覮汼）が用いられ，籍型，パド ル型などの摜拌羽根を適当な速度で回転させる。沈殿池 には污泥捸寄機, 多数の池がある場合, 掻寄機をのせて 一池から他の池に移動させる移動台が設備され，1日 1 回ないし数回, 沈殿池に沈積する沈殿物を池の底の一端 に蛋さ寄せ，そこから池外に排出できるようになった。 型式は走行式やフライトコンペア式などがある。さらに 走行式污泥掻笴機の揂寄操作, 走行, 数池の移動, 池の 選択、各種故障検出保護など一切を完全自動で運転でき るすのも完成された。

旧来の薬品混和, 凝集, 沈殿の各操作はかなり大きな 池て順次行なわれてきたが，これらの操作を比較的小さ な単一の慒内で行な5ことのできる急速凝集沈殿装置が 急速に普及使用されるよらになった。その形式には種々 あるが，スラリ接触型のスラヂブランケット装置，スラ リ接触循環型のアクセレータ装置が実用されている大部 分であって，従来の横流自然沈殿式に対し, 上向流強制 沈殷式ということができる。なおスラリ接触循環型装置 にはアクセレータの他, 沈殿物の强奇機が併設されてい る IS 型アクセレータ, サイクレータ, スラジブランケ ット型との折克型の SR 型アクセレータなどが実用され ている。一方横流式沈股池と同じ目的で円型クラリファ イヤ・シックナが, 従来す使用されてきたが, 非常に多 く使用されるよ5になり, 特に非常に大きな直径のもの も実用されている。

急速沪過装置も進歩し，表面洗條設備（固定式执よび 回転式）が普及し，逆流洗淮空気洗涤から浄水による 洗涤がはとんどである。沪過水流量自動調節升も非常に 多く使用され, 空気圷操作, 電気的操作で自動化, 遠隔 操作が可能となり，乙たがって汇過，洗涤のサイクルの 完全自動化が行なわれた。汇過速度も従来の $100 \mathrm{~m}^{3} / \mathrm{m}^{2} /$ 日程度から最高 $250 \mathrm{~m}^{3} / \mathrm{m}^{2} /$ 日も実施されている。

浄水の薬品处理に薬品注入設備も完成され, 溶液式の
外石灰などの粉体を乾式で精度よく供給注入できる装置 も数多く実用化された。さらに流量, 液面水位, $\mathrm{pH} と ゙$ の自動検出，それと関連させた薬品自動調整，比例制御， 升操作などが急速に発達, 実用されている。

ボイラの大型化, 高圧化ととすに戦時中に発明された イオン交換樹脂の利用が急速に発展し, 軟化, 純水処理 が著しく進歩した。陽イオン交換, 脱気, 陰イオン交換 の組み合わせ，さらに混床式などの方式により，超高仕 ボイラ給水，トランジスタ，原子力工業向けなどに超高 純度の純水が得られるようになった。粒状イオン交換构 脂の外飞液状, 膜状のものも最近実用化の緒につき, 将 来大い《進歩すると思われる。

廃水処理の分野は, 工業の復興, 技術進歩とともに急 激に認識が深まり，河川水などの污染る見逃がすことが できない状態になってきたので，処理の研究とともに， 急速に実施されてきた。廃水処理の内容も, 油, 紙パル プ白水, 原料蒸者黑液, 染色, 各種粉鹿, 鍍金の青化塩, 重金属，精糖廃液など，種々雑多きわめて広範に拉よん でいる。処理法としては薬品添加による化学妈理, 嫌気 性敉生物による消化（醇）方式や，好気性生物による 活性污泥, 撒水汇床などによる方式, それらの組み合わ せ、下水や屎尿などとの合併処理も行なわれるようにな った。

廃水処理では, 概して有害, 不要の混合物の無害化が おる゙ではあるが，さらに有用物質の回収，転化などの研 究も着々と進められ，一部実施化されつつある。経済的 にも，技術的にも今後この方面は大いに開発されるであ 万5。

\section{粉 砝 機 . 笁 分 譏*}

I. 粗 䂶 機

\section{沢渏㕌**}

粗硪機として，現在最む多く使用されているものはジ ョークラッシャ, ジャイレートリクラッシャ, コーンク ラッシャ, 衝撃クラッシャなどがある。ジョークラッシ ヤは 1858 年ブレーク (Blake) により発明され,ブレー キジョークラッシャといわれ，また，ジャイレートリタ ラッシャは 1880 年ゲート (Gates) の考案によるもので ゲートクラッシャとして世界の隅々まで普及された。そ の後幾多の改良が加えられ，現在のよ5な形態を整える よ5になった。これらのクラッシャが実用化されはじめ

* 昭和 36 年 5 月 30 日受理

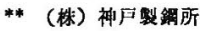


てから粗破工業は非常な進歩を示し，パワーショペルの 使用と相まって次第に大形化され，同時に細粒の製品生 産のため、コーンクラッシャ, 衝盤クラッシャの出現を みるにいたり,この間破碀機構に関する研究す進み, 幾 多の優秀な種々のクラッシャが改良製作されている。

かが国に扎いては第一次世界大戦の前後から化学工業 用の単位操作機械の一つである破碀機のメーカは次第に 発展をとげて行き, 大戦後の反動期から昭和の初期の不 況期にかけて一時苦境をかこったが，昭和 6 年の满州事 変以後よ 5 やく好況時代を迎元, 栗本鉄工所, 住友機械, 横山工業など化学機械を専門とする機械工業会社す多数 創立された。昭和 14,5 年頃にはようやくわが国の破确 機製造業は一応の形態をととのえ，当時世界でる大形の 右翼を行く 30 番形 $(1520 \times 4350)$ ジャイレートリクラ ッシャが神戸製鋼所で製造され，満鉄の鉄鉱石破砕に使 用された。第二次世界大戦への突入により次第に軍需工 業がさかんになり，この種破啸機は生産制限を受けほと んど製作不能に近い状態におかれ，昭和 20 年の終戦を 迎えた。戦後は鉄鋼をはじめ, その他の材料, 消耗品, 罆金の値上り，電力の制限などによる打揧も，破确機メ 一カにあっては痛切で, 各メーカとも事業の縮少を余儀 なくされた。しかし, 昭和 20 年頃から電源開発が緒に つき各地でコンクリート用骨材の製造のためまた，七 メント工業の設備增強などが進められた関係上，急速に この種クラッシャの需要が増大して行った。第二次大戦 中就よび戦後数年の虚脱状態を考えれば技術の向上は10 年間停止していたといっても過言ではない。この空白期 間をばんかいし，急激な設備払充と各産業の開発に即応 するには戦前からの国産技術では，能率の点で欧米との 技衍格差が著しく，昭和 26 年神戸製鋼所，昭和 28 年横 山工業, 昭和 29 年久保田鉄工の 3 社が技術導入を行な った。神户製鋼所は古くから破砕機に関するわが国最大 のメーカとして知られていたか，アメリカのアリス・チ ャーマズ社との技術差が大きく、破确機および粉确ミル 全般にわたり技術導入を行ない, 構造の簡素化, 軽量化 などの技術および材料の改善をその目的とした。横山工 業が導入した西独のハゼマグ社の技術は破破物を高速回 転するロータで加速し，反撥板に連打させることにより， 運動量変化を有効に利用して破碎を行な5インペラブレ 一カについてであり，また，久保田鉄工が導入したアメ リカのケネディ社の技術はギャレス式ジャイレートリク ラッシャを中心とした各種破破機に関してである。これ らの技術導入は, わが国の破挽機メーカの技術的発展に 役立ち, 旧来の設計が改善され，最近の各工業における 設備增強, 生産性の向上の一翼として, その活躍がめさ ましく, また, 台湾, フイリッピン, 東南アジャ方面へ
の輸出も石炏石, 鉄鈗石の破确用, また土木工事用とし て進展しつつある。

各クラッシャの進步の概要をあげればまず, ジョーク ラッシャは従来軸受部に面軸受を使用していたが，ころ 軸受にかわり，給油ポンプの設備，軸受焼損の危惧がな くなり，作業の安全性を高めている。また破砩室が深く 破确角度が小さくなり，裏板の形状もストレート形から ノンチョーキング形に変わり, 破破能力が倍增してきて いる。たとえば JES 臨時第 315 号に制定された 7 番形 で出ロすきま 125 粍の場合 $91 \mathrm{t} / \mathrm{h}$ であったが，現在では 同一寸法のもので各社により多少差異はあるが, 120 $190 \mathrm{t} / \mathrm{h}$ の能力をもってている

ジャイレートリおよびューンクラッシャにおいては破 䃏頭の支持を油圧で行ない，出口すきまの調整容易, 異 物の安全排出などに留意し，取り扱いおよび安全性を高 めたものが出現したことは特記すべきことである。軸受 部にはまだほとんど面軸受が使用され，横軸部の一部に ころ軸受および玉軸受が使用されている現状であるが， ジョークラッシャと同様, すべての軸受部にころ軸受を 使用したものが出現するのも近いことであろ5。すでに コーンクラッシャに扎いて軸受部はすべてころ軸受を使 用し、コンケーブは円周上垂直に配置された油圧シリン ダによって弾性的に連結され,かつ, ギャレス式のものが 西ドイッの W.D.Gröppel 社によって製作されている。

衝撃クラッシャはロータから腕をだし, その先にハン マをつけ衝撃破硡を行な5がハンマが, 可動的なるの と, 固定のものがあり, 後者が新しく発展しつつあるイ ンパクトクラッシャで, 早川鉄工の反撥式粉碎機, 横山 工業のインペラブレーカなどがそれである。この種破磁 機は破破比が大きく, 打撃破砕効果は圧樎形破啸機に比 して効率がよく，また機構も簡易である。このような利 点をるった衝撃クラッシャにも，ハンマおよび打撃板、 反撥板の磨耗, 巨大な原石を一挙に破确するための機械 的および材料的な検討など幾多の問題がある。

以上簡単に粗确機の進歩の状況を説明したが今後さら に一層優秀な粗㸴機の出現が望まれるところである。

II. 微粉碀機・笠分機*

細 川 益 男** 松山 卓 蔵**

微粉砕機 わが国に括ける微粉破機は近代にいたる

* 昭和 36 年 6 月 21 日受理

**（株）細川铁工所 
わが国主要粉确機メ一カ生産実績表

\begin{tabular}{|c|c|c|c|c|}
\hline & & 昭 26 & 27 & 28 \\
\hline 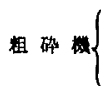 & $\begin{array}{l}\text { 台 } \\
\text { 重量 to } \\
\text { 金愘頁千 }\end{array}$ & $\begin{array}{r}50 \\
198 \\
43,396\end{array}$ & $\begin{array}{r}125 \\
656 \\
163,572\end{array}$ & $\begin{array}{r}1,109 \\
5,592 \\
1,165,576\end{array}$ \\
\hline 粉碎機 & $\begin{array}{l}\text { 台 } \\
\text { 雷量 to } \\
\text { 金新千 }\end{array}$ & $\begin{array}{r}220 \\
143 \\
29,517\end{array}$ & $\begin{array}{r}248 \\
139 \\
29,064\end{array}$ & $\begin{array}{r}2,259 \\
5,995 \\
1,135,071\end{array}$ \\
\hline
\end{tabular}

（立兼機械工莱会誌に上る）

$\begin{array}{rr}29 & 30 \\ 786 & 699 \\ 4,130 & 3,155 \\ 864,556 & 728,337 \\ 2,499 & 2,612 \\ 8,401 & 4,928 \\ 1,491,230 & 835,864\end{array}$

32
1,181
5,792
$1,950,480$
2,931
6,086
$1,973,768$

34

1,318

4,871

$1,373,420$

1,115

4,374

$1,282,798$
まで, 捣臼(人力, 水力), 挽臼, 薬研などで見るべきす のがない。勿論, 西洋諸国においても, 石器時代の手石 (hand stone), ギリシャ, ローマ時代の轱石 (saddle stone), 手目 (handmill) を経て, 動力源として水車, 風 力, 牛馬を用いた挽白, フレットミルから, 苲気力を用 いた（1780年）頃より初めて機械化の時代に入ったこと を思觉ば, 粉碀機の歴史は古くて新しい。特に 1867 年 の連続式ボールミルの発明以来多様な機種と大型ミルの 産業革命時代に入ったのである。特に 19 世紀末にチュ ーブミル，20世紀初頭のコンパウドミル, Harding (1925 年）のコニカルボールミルなどが石炭, 鉱石, セメント 工業界の嚯進に寄与してきたのである。ポールミルはそ の単純さの故に，また，大型化が容易な点で沉用された が，一面研究の難しさのため未だに確立した理論は少な く, 経験に依存することが多い。戦後はポールミルを airswept closed circuit 系にしてェアセパレーター(Gaeco, Sturtevant, Raymond 型), 変形サイクロン型な どの風力分級機の採用が盛んで，100 1,000\%程度の大 循環量 circulating load の下に粉确能力の向上, 粒度分 布の適正保持, 粒度ハシラッキの減少が微粉确機としての ボールミルの進歩の方向となった。またボールミルの改 良として大直径 $(5 \sim 8 \mathrm{~m} \phi)$ 短胴型の Aerofall mill, コ= カルボールミルの一変形と見なされるトリコンミル，媒 体ボールと破料のミル内適正配列を目的としたスパイラ ルライナ,スレヒテンライナなども重要な進歩であり, 発 明である。湿式ボールミルに代って塔式磨碀機(1952年) はわが国独自のものであり，特殊な部面に使われている。 Ring-roller mill は石炭, 粼釷石, 酸化于タン方面に慣 用されている。振動ミルは今後発展すべき機種で硬度の 大なる摩耗性䂺料のミルとして開発されよう。高速度衝 撃式粉啸機は軟質材の微粉啸に沉用されており, 戦前よ りある奈良、細川、ヤリヤなどのディスメンブレータ型 のあのと細川ミクロンミルがその代表であった。戦後は アメリカのマイクロパルペライザ社の設計のアトマイザ
（パルペライザ）が，ランナ周速を 80〜 $100 \mathrm{~m} / \mathrm{sec}$ Kま で上け゚ることにより，進出してきた。この方面で誇るべ き国産技術の一つは B.H.C.（軟化点 $60^{\circ} \mathrm{C}$ ) 原料を無 冷却で 325 メッシ迄微砕するに成功した細川ミクロンミ ルとミクロンセパレータの組み合わせである。また䂺料 中の異物を, その粉确能の差によって，粉破々同時飞異 物分離を行な5スパーミクロンミルの設計（1951 年）。 また誇るべさすのであり，すでに海外にも紹介され，技 術輸出の一端を担っている。ジェットミルの歴史はがな り古く, Principles of Chem. Eng. の初版にもすでに紹 介されている程たが，わが国では戦後酸化チタン工業の 導入とともに数台の Micronizer（1953年）が輸入され。 また最近農業方面などの特殊用途に不可欠のものとなり つつある。参考まで飞産業機械工業会の調査による有名 メーカ最近の粉碀機生産実續（昭 26〜 昭 34）を表示す る。本調査は 30 60 工場について行なわれたるので完 全なものとはいえないが, その一端を案ら参考とした。

箱 分機節分機では戦前よりあるタイロック型, グリッズイ型などは鉱石，石炭方面に慣用されている。 戦後化学工業方面では数十メッシ程度以下の篩分が要望 され徳寿工業所のジャイロシフタ, 細川鉄工所のミクロ ンシフタ, 汽車会社の K.S.K. 振動節, 横山工業の棈円 振動篩, 早川鉄工の共振篩, 神鋼電機の振動篩などそれ ぞれの特徵をるったるのが国際見本市などに展示されて いる。現在の篩分機の傾向として，電磁振動に見られる ごとき高い振動数と小さい振幅よりも，一層大きい振幅 (5〜15 mm) とそれに見合ら与 5限りの高い振動数の適 用である。そのために防振ゴムの発達が大きく寄与して いる。本章の結語として，粉体技術方面に批いてわが国 の技術は欧米に比して遜色なくまたある部門では優秀な 機械もあること，また今後産業界，学界一丸となった 努力により，外国技術より独立した新分野を開発しらる 時代に入ったことを強調したい。 


\section{真空 装 蛋*}

中川 洋**

\section{1. 真空技衙の化学工業への応用}

最近，真空技術の進歩発展は誠にめざましいるのがあ り,特に化学工業方面への応用は著しく㹤張されてきた。 従来常圧下で行なわれていたプロセスが真空下で実施さ れるよらになったり，または比較的低真空で行なわれて いたものがょり高真空下で行なわれるよ5になった。こ のことは従来のプロセスでは得られない優れた製品の生 産が可能となっただけではなく，新しい合成，精製，分 離などを可能にした。特に最近高分子物質の新しい開拓 が盛に行なわれていて，熱的にまた化学的に不安定な物 質の操作取り报いに真空が応用されることは常識となっ た。

るらろん, 化学工業に真空が応用されたのは極めて昔 のことであり，わが国の化学工業の摇籃期からたとえば 石油の精溜などに外国から輸入された機械に附属して真 空ポンプがあったなど，化学工場では相当にありふれた 存在であった。しかし戦前の真空化学装置は大部分が真 空蒸溜, 真空精溜装置であり, 真空ポンプも往復動のピ ストン型か水封式のいわゆるナッシュ型に限られてい た。装置の粫造も，また使われた配管，并，計器などの 部分品す今日から見れば，全然真空技術的な考虑が払わ れていなかったといってる過言でなく，誠に旧時代的な 装置であった。

戦時中旧海軍が初めて高真空蒸溜による潤滑油の精製 を研究し，この技術が, 戦後荒廃した化学工業の復興の 一翼として，当時統制外淿あった魚肝油を分子蒸溜によ って，輸出用の高単位ビタミンと一般油脂とに分けると いう時期に適した工業として結実した。その頃から塩化

*明和 36 年 7 月 5 日受理

**日本理化工莱 (株)
ビニールの生産す行なわれるよ5になり，当時としては 誠汇「有難い」物質一今日ではその有難味も大部薄ら いだが—の製造に不可欠な可塑剤の精製が分子蒸溜の 技術によって極めて急速かつ高能率で工業化された。同 時にわが国の化学工業化一つのエポックを画した合成織 維の製造工程上，真空下の反応とい5プロセスが行なわ れるよ5になり, 真空化学装置も新しい応用面の一一步を 踏み出した。

ここまでくると真空下に批る種々のプロセスが極め て特異性があり，かつ重要なことが広く認識され，その 応用分野は燎原の火のことく広がった。また従来真空下 で行なわれたプロセスをより高真空より高能率㑟良し よ5とする企てす盛ん行なわれ，この二つの傾向は今 日でも続いている—といらだけでなく今日であ增々そ の傾向が強くなっている。今日では化学工場に多かれ少 なかれ，真空装眉を設置していない所はなく，その分野 も, 真空蒸溜, 真空精溜, 分子蒸溜, 真空㛺燥, 真空脱 気, 真空含浸, 真空調湿, 真空汇過, 真空榆送, 真空蒸 発, 真空濃縮, 真空晶出など枚挙に眼がない。

\section{2. 基礎的ならびに応用研究の進展}

前述のよ5反化学工業に真空技術が厸く使われるよ5 になった経過はその当時発表された研究報告, 技術報告, 総説のよ5な文献に最す良く表われていると思われる。

これを整理して見ると表 1 のよ5になり年々增加の傾 向にある。るっともこの種文献は化学工業に関係ある真 空関係といら線をどこに引くか問題であるか，表の数字 は著者の私見によるものとはいいながら，化学工業にお いて真空に関する関心が年々深まりつつあることは確言 できると思5。

\section{3. 排気装置の進歩}

真空装置には真空排気装置が不可欠であることは論を 俟たないが，真空装置の発達に刺㦸されて真空ポンプも 非常な発展をした。古い化学用の真空装置は往復動ピス トン型のるのと，水封式のナッシュ型が大部分を占めて

表 1 最近の真空化学装置および真空下における化学的操作の文献数（日本）

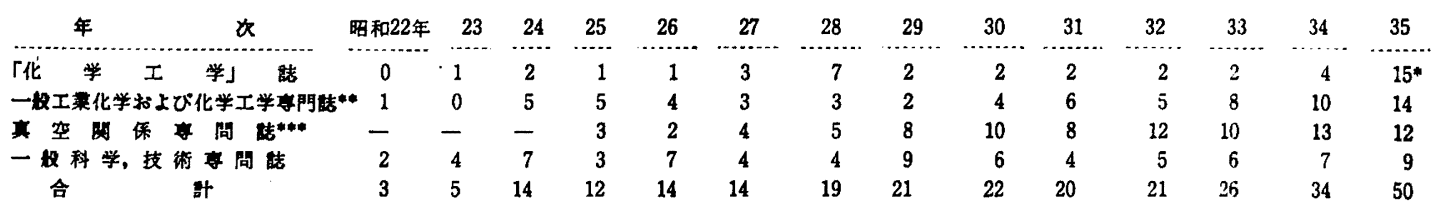

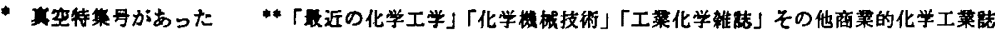

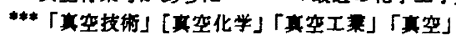


いた。真空技術の発達により機械的ポンプとしてゲーデ 型，センコ型などの油佪転ポンプが非常に優れた性能を 示すようになったので，戦後この種ポンプを化学工業用 に使打 $ら$ とする試みがなされたが，化学工業ではポンプ を腐蝕したり，機能を害する有害な気体を引くばかりで なく，水または水蒸気ですら，この種ポンプの機能を著 しく劣化させることが判明した。このため同じ油廻転型 であっても，潤滑油が一度大気压に出て循環するキニー 型のポンプは油精製が楽に行なわれるので化学工業の迴 転真空ポンプとして本命になってきた。数年前より水蒸 気を吸引してもこれを瓦縮せずに排気してしまい潤滑油 中に水を作らないガスバラスト型式のキニーポンプがで き，化学工業用に重用されている。

古くからスチームゼット，水ゼットなどのポンプが化 学工場で使われているが, 前述のよ5に油迴転ポンプが 進歩したことと，これらのエゼクターの効率があまり高 くなく設備費す高くつくために非常に大型の装置の排気 用とか, 非常に有害な気体の排気用以外は油趣転ポンプ に置き換えられている。

この他高真空用の油拡散ポンプ,油エゼクターポンプ, メカニカルブースターといった高性能のポンプが盛んに 化学工業の方面に進出している。しかしこれらの高真空 ポンプはもともとの生い立ちが清浄な気体を引く場合に ついて発達してきたために，化学工業のいわゆる污れた 気体を引くと充分の性能が出なかったり, 機能を阻害さ れることも多かったが，最近ではとの対策す考えられ実 用上何らの不便も感ぜられなくなった。

真空装固の化学工業への応用の進展にともなって, 真 空ポンプの進出る当然多くなった。今日真空ポンプの生 産は年間約 4 億円に達するが，このうち約 $80 \%$ が油廻 転ポンプ拉よび油拡散ポンプなどの高真空用ポンプであ りまたこの5ち約 $50 \%$ が化学工業用に使用されてい る。この方面の統計は最近まで業界の機関がなかったた め, 詳しい調査が行なわれていないが, 最近数年間の真 空ポンプ (油廻転, 油拡散, 油噴射などの高真空用ポン プ）の生産実績は表 2 のよ5になっている。ここ数年非 常に生産額が上䄯し，世の好況とともに真空ポンブが普 及されていることを示している。昭和 25 年頃には恐ら

表 2 真空ポンプ（油畐転ポンプ, 油拡散ポンプ, 油噴射ポンプの生産実績）

\begin{tabular}{|c|c|c|}
\hline 1956 年 & 62 億 0000 万円 & 8 供 4000 万户 \\
\hline 1957 年 & 6 傹 2000 万円 & 1961 年 (予想) 10 億 \\
\hline 1958 年 & 5 供 2000 万円 & 1965 年 (郡画) 17 供 \\
\hline 1959 年 & 7 供 3000 万円 & \\
\hline
\end{tabular}

く一千万円に達しなかったものと思われるが，誠に今昔 の感洏えない。

\section{4. 真空蒸溜装置の叱達}

一几に真空蒸溜装置といっても種々の型式がある訳で その発達も各型式によって大いに異なっている。すず単 純な回分式真空蒸溜装置についてはその基本線はこれと いった発展もない。すでに古くから化学工場で運転され ており，前述のように排気ポンプが進歩したことや，従 来より高真空の運転が行なわれるよ5Kなったこと, (可 塑㓮の精製では $0.1 \mathrm{~mm} \mathrm{Hg}$ 以下で蒸溜が行なわれる。 戦前は $100 \sim 30 \mathrm{mmHg}$ くらいが普通であった）加熱方 式が伝熱媒体の進歩によって高能率になったことなどが 目立った発展である。

連続式の真空蒸溜または蒸発装置は非常に進歩をとげ た。戦前はあまりこのようなプロセスが行なわれなかっ たためか，わずかに石油精製の部門にその例が見られる 程度であったが，戦後はまず粉末ジュースの製造に高能 率な連続真空蒸発装置がつくられ，ついで海水から真空 多重効用罐によって淡水と同時浪食塩を採取する装置が 作られた。さらに油脂関係でも脂肪酸のフラッシュ蒸溜 など戦前には見られなかったよ5な高能率な装置が続な として建設された。この他蒸発効率を高め瞬間的な蒸発 によって処理物質の加熱時間を極度に短かくするよ5な 種々の蒸発器の形式が考えられている。

分子蒸溜は高真空蒸溜の一つであるが，高真空下に括 いては比較的低温度で蒸発が起り得る点と，流下膜の型 式による蒸溜加熱時間が短縮されるとい5二つの利点の ため従来蒸溜不能と考えられていた熱的不安定の物質が 極めて能率良く回收精製される。最も成功した例はやは りビタミンAの濃缩である。表 3 は戦後建設された分子 蒸溜装置の大きさの変遷であって，能力型態とも格段の 進歩を示していることがわかる。

真空精溜装置も戦前から工業化されていたが，特に最 近になって一理論段当りの圧降下をできるだけ小さくす る研究が行なわれている。従来石油の真空精溜に用いら れている泡鐘塔では，一段当りの圧降下は小さくとも3

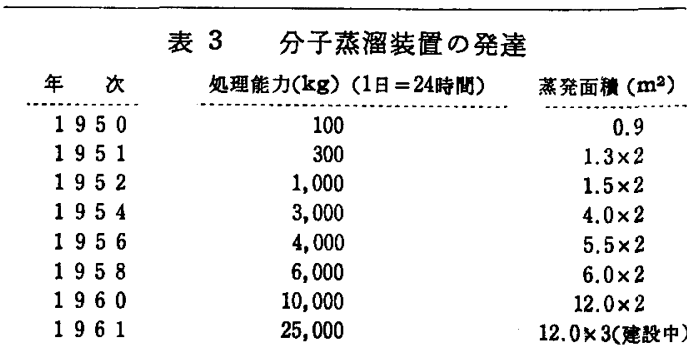


表 4 高真空装置の生産実績ならびに計画

\begin{tabular}{|c|c|c|c|}
\hline 1956年 & 11輍円 & 1960年 & 23稘 2000 万内 \\
\hline 1957年 & 13愎5000万円 & 1961年（予想） & 29僚円 \\
\hline 1958年 & 13偾 4000 万円 & 1964年 (" ) & 50 僚円 \\
\hline 1959年 & 17稘 6000 万円 & & \\
\hline 注： 1 . & 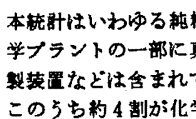 & 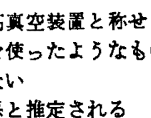 & $\begin{array}{l}\text { のののみで, 化 } \\
\text { たとえば石油精 }\end{array}$ \\
\hline
\end{tabular}

$\mathrm{mm} \mathrm{Hg}$ ほどあり，50 段の精溜塔では $150 \mathrm{~mm} \mathrm{Hg}$ の压 降下があり筒頂をいかに高真空にしても蒸発罐では少な くとも $150 \mathrm{~mm} \mathrm{Hg}$ になった。最近実用化されたターボ グリッド精溜板では各段当り $0.5 \mathrm{mmHg}$ という小さ いものができ，これならば 50 段でもわずか $25 \mathrm{mmHg}$ の压降下ですむ。したがって同じ精溜です原液の温度を $100^{\circ} \mathrm{C}$ 近く下辛ることに成功している。

この他, 充填塔でも充媜物の形状, 充媜方法の改良な と゚とよって次第に高能率な真空精溜装置が建設されてい く。特に最近熱的に不安定でかつ沸点の近接した成分を 分ける必要が多くなり，ますます真空精溜の必要性は增 大している。

\section{5. 真空含漫、真空乾燥などの装置の進歩}

これらの装置は戦前からも相当実用化されて扣り，特 に目立った進歩はないが，他の真空装置と同じょうに地 道な進歩を続けているといえる。真空下に括ける乾燥操 作は常圧下とは全々異なった様相を呈し，化学工学的な 観点から色々と研究されている。特に生物学的諸試料の 真空凍結乾燥装盾は戦後いち早く実用化された。今日で は1回数 $10 \mathrm{t}$ の水溶液を凍結真空燥乾する装置が造ら れている。

含漫装置も原理としては極めて簡単でありながら，実 用化汇当っては色々と問題が多い。今日では 1 回処理量 $10 \mathrm{t}$ とい5大型の装置が造られている。

\section{6. その他の真空装置の進歩}

液化ガス眝槽, 特に液体酸素, 液体窒素の眝槽に真空 断熱を使 こことも戦後急速に実用化された。戦前は数 $l$ の小型の魔法瓶に応用されていたに過ざないが，今日で は $10 \mathrm{t}$ 程度の眝槽が造られている。また水素, ヘリウ ムなどの極低温ガス液化装置, およびその眝槽には真空 断熱は不可欠の技術となった。

無沪洩装置と称すへき装置，すなわち有害な放射性物 質とか空気中の酸素や水分と反応し易い物質を操作する 装置の気密す真空技術を応用して行なわれる。この種装 置は表面上は真空装置とは考えられていないが，設計製
作には真空装置と同様の考虑を払 らべきものである。原 子炉関係；括よびその附属品としての燃料取出装置など はこの好例というべきでこの種装置が国産で充分できた ことも著しい進歩である。

この他真空装置はその種類が極めて多くとてもこの小 稿で詳述することは不可能であるが，とるかく真空技術 の進歩が急速であるために，その化学工業方面に和ける 進歩すまた急速で日進月歩の観があり, 他の化学工学部 門比比較してその進歩をたどることすら困難である。し たがって急速な進展止る所を知らずということが結論で あろうか。表 4 に最近数年および今後数年にわたる高真 空装置の生産実績および生産計画を示したが，この結論 を示す最も端的な表現といえよう。

貯槽・カスホルダー*

$$
\text { 石 并寛** }
$$

従来詝槽とは主として液体の眝蔵に供する容器をいい ガスホルダーはガス体のみの眝蔵を目的として建造され た容器の呼称であった。ところが近年液化ガス (L.P.G., L.M.G.のごとき) の出現により, 両者の区別が判然と せず液体貯慒であると同時にガス体貯蔵器すなわち, ガ スホルダーでもある容器の要求が相当量生ずるにいたっ た。しかし本項に打いては上記両者の貯蔵を兼ねる容器 については一括後述することにし，一般的概念に基づく 眝槽およびガスホルダーの種類, 歴史, 発展過程につい て概要を述へようと思 5。

\section{1. 賍槽の種類および構造概要}

1.1 横型定置式鋼板製眝槽 本眝槽は通称枕タンク ともいわれ最も古くから使われた容器で本体は鋼板製円 筒型，両端に鋼板製鏡板を設け，鋼製架構もしくはコン クリート架台上飞設置される。本貯槽は比較的少容量の 眝蔵目的に供せられ, 後述の液化ガスの貯蔵るその出現 の初期に抋いては専らこの型式が採用されていた。

一般には鋼板製全溶接構造であるが，その貯藏内容物 により特種鋼，各種非鉄金属などが使用される。また本 腙槽は小型であるため, 内容物を相当程度加圧下に貯蔵 し，または保温，もしくは保冷することにより，相当程 度の高温液, むしくは低温液の貯蔵に供することができ る。

$1 \cdot 2$ 堅型鋼板製貯槽 本貯槽は横型定置式にくらべ

\footnotetext{
* 昭和 36 年 5 月 29 日受理
}

** (株) 石井鉄工所 
比較的, 大容量眝蔵の場合に広く用いられる型式である。 本体は鋼板製円简型，下端は鋼板製底板，上部に鋼板， 型鋼製頂板を備えた全溶接構造である。たたし，その眝 蔵内容物の種類および柠蔵条件に応じ特種鋼または各種 非鉄金属などが使用される。な招本眝槽は一般的には眝 蔵液体を常温, 常圧下に貯蔵する目的に使用されるが時 には液体表面にて大気圧より稍高い圧力下に眝蔵する場 合および貯蔵液体をその種類に応じ適宜加熱する場合な どがある。前者はその加圧程度に応じ，頂板および底板 をドーム状に設計するなど，耐圧構造とし，後者はその 必要とする加熱のため槽内に蒸気などによる加熱管拉よ び温度の均一を計るための詝槽内挰捧装置を備えた構造 とする。

以上の他詝蔵液体が非常に蒸発もしくは揮発し易い場 合, その苲発を可及的に防止する構造として竪型詝槽に お゙ける固定式頂板を改め常に頂板下面が詝蔵液面に接し 液の增减に応じて上，下に移動する型式，すなわち，浮 屋根式貯槽が考案され，現今原油の貯蔵などに超大型の すのが多数建設されるにいたった。本体は一般朢型貯槽 と同様に鋼板製全溶接構造であるが，頂部に頂骨および 頂板を具備せぬため風圧などによる強度上の見地から側 板頂部，外周に対風材（ウインド・ガーダー）として鋼 板および型鋼製補強リングが設固されている。

詝蔵液の增減とともに年降する浮屋根は貯槽内径より 稍少直径に設計された。巨大な浮子（ウキ）で，その本 体側板内壁に接する部分（直径の相異により若千の間隙 あり）には特種構造のシール装置を具備し, 槽内に発生 した気化ガスの漏出を可及的に防止し，また外部からの 雨水の流入をあ防ぐ構造俘計されている。このシール 装置の構造に金属を使用したいわゆるメタリックシール 扣よび人造ゴムなどで造られたチューブを使用する，チ ニーブシールすしくはプレッシャーシールの 2 型式があ り, 気密程度を考虑されて漸次, 後者が多く採用される にいたった。

浮屋根上に降下した雨水は屋根中央部から槽内に通じ 本体側板下部に接続されたドレーンホースもしくは蝶番 式継手により折たたみするドレーンパイプにより，槽外 に導びかれる構造となっている。

次に竪型詝槽で夜化ガス，たとえばL.P.G., L.M.G. などを常压，低温下に眝蔵しょうとする傾向が漸次多く なっており，その内容物の常圧下の温度にしたがい耐低 温鋼材（キルド鋼のことき）るしくは耐低温非鉄金属な どを用材として建造される。この場合勿論眝槽全外面に 適当なる保冷工事を施行せねばならない。特に L.M.G （液化メタン)のごとくその常圧下に打ける温度 (一)百数 十度にも拉よぶ場合は詝槽の用材はもとより，設置され
る基礎工事がれまた容易なものではなく，貯槽自体の 用材，保冷工事と相俣って各界の挙げて研究されつつあ るところである。

\section{2. ガスホルダーの種類および棬造概要}

都市ガスを始め各種化学工業用ガスの貯蔵用カススホル ダーは型式から分類して下記の 3 種類となる。
1）有水式ガス溜
2）無水式ガス溜
3) 球型ガス溜

$2 \cdot 1$ 有水式ガス溜 ガスホルダー中最も古い歴史を 持ちしかす現在な挌各方面炕多数使用されている型式で 構造の安全性と比較的建設の容易なところからわが国で ○明治年間から都市ガス眝蔵用として数多く建造されて いた。

本ガス溜は水封により気密を保つ構造で，ガスを眝蔵 する部分すなわちガス槽の層数により単層式, 複層式, 三層式など，その容量の大小にとすなう種々の型式があ る。本ガス溜の最下段は水槽で, 水槽側板外側㹸設けた 多数の鋼製支柱をガイドに上記各ガス槽が眝蔵ガスの普. 減に応じて年降する構造である。ガス槽の各槽接続部す また水封構造により気密を保たれており最上段ガス槽に は頂骨によって支えられた頂板が取り付けられている。 本型式のガス溜す逐年大容量のものが要求され，日本に 扗いては，先年東京ガス滝之川整圧所構内に建造された $175,000 \mathrm{~m}^{3}$ のものが最大である。

$2 \cdot 2$ 無水式ガス溜 本ガス溜は乾式ガス溜とすいわ れ, その歴史は有水式にくらべかなり新しく, 欧米におい て使用され始めたのは今から約 50 年前の 1910 年前後と 聞いている。わが国炕いては約 30 年前の昭和初年東 京ガス,鶴見, 大森などの各製造所にドィッ M.A.N 社か らの輸入で計 4 基が建造されたのが最古のるので当時の 石川島造船ならびに, 石井鉄工所により各 2 基宛が建設 されたすのである。引き続いて純国産器としては昭和電 工に建造された無本槽ガス溜 2 基があったが，現在はそ れら戦前の無水式ガス溜はすべて撤去された。戦後建設 された川崎製鉄，大阪ガス，八幡製鉄などの該ガス溜は いずれるドイッ M.A.N. 社より輸入されたものである。 無水式ガス溜は鋼板製直立円筒状もしくは多角筒状の本 体に頂板扣よび底板を有し，その簡内に特種構造のシー ル装置を周辺に装備したピストンを水平に備えたもの で，ピストン下方に送入されるガス圧によってビストン が上年する構造である。すなわち送入ガス量に応じてピ ストンが年降するため, 貯蔵ガス压は常にピストンの重 量によって（必要に応じ適量の荷重をのせる）一定に保 たれる構造となっている。鋼板製本体は風圧および地震 
などを考虑し充分なる補強が施され，また M. A.N. 式 のるのはそのシール装置に使われる特種鉱油を循環させ るポンプ装圆をも具備している。

無水式ガス溜の特徵を挙げれば,

1）有水式にくらべ最も鋼材量を多く必要とする水槽 がないだめ，所用材料が連かに少なく，ある程度以上の 容量のものに対してはその建造費が相当額逓减される。

2）所用鋼材量の少ない上水封用水を一切使用しない ためガス溜総重量が有水式にくらべ非常に軽くしたがっ てその基碟工事費が低廉である。

3）有水式と異なり水封用水を一切使用せぬため眝藏 ガスは常に乾燥状態を保持できる。

4) 有水式の場合（特に多段式の場合）はガス槽の年 降高さにより眝蔵ガス压炕高低を生ずるが無水式の場合 は, 前述のごとく器内に装備したピストンが詝蔵ガス量 にしたがって年降する構造のため常に眝藏ガス压が一定 である。

次に有水式にくらべその欠点を挙げればM.A.N. 式無 水ガス溜のシールには特種の流動性磺油を使用し該油は そのシール構造のわずかな間隙から側板内壁に沿って, 底部に流下されることによりガス気密を保持する構造の ため，底部に溜った流下磺油を汇過の上ポンプにより再 度ガス溜頂部に送る装置を具備する。そのため常にポン プを運転する動力を必要とし，かつ日々の看視を要する 不便がある。るっとも右に対しては流動性の磺油を使用 せぬシール構造が考案され，そのモデル実験に成功して おり，これによればポンプ運転用動力は不用となる。

次に上述の無水式ガス溜はそのシール部分に流動性磺 油の他必ず油脂類を使用することになっているが，眝藏 ガスによっては一切の油脂類をす避けねばならぬ場合す あり，その場合には次のことそ構造のものが使用されて いる。本ガス溜の大体の構造は前項の M. A.N. 式その 他の無水ガス溜に酷似したすのでたたピストンの気密部 分にはゴム製の膜を使用した点が相異しており，本体側 板内壁中央部とピストン周辺とをゴム製円筒で結んだい わゆるバルーンタイプで構造は極めて簡単のすのである が，機構上あまり大容量のすのは望めず目下の処 3,000 ないし $5,000 \mathrm{~m}^{3}$ 程度のものか限度とされている。

2.3 球型ガス溜 近年都市ガスの需要が急激に上年 したため，その製造供給に飛躍的発展を遂げ，まず製造 火は高圧精製が行なわれ，供給すその地域の拡大にとも ない, 逐次高压輸送が開始されるにいたった。高圧精製 されたガスはいずれ高圧輸送する必要上製造所に設置さ れた高圧ガス溜に貯藏しここれ導管により供給地域に 設けた整圧所に高生輸送される。この整圧所にるまた受 け入れ用高圧ガス溜を有しここで初めて適当压力に減
圧されて,各需用家に供給されることになる。これらに使 用される高圧ガス溜はいずれる最す合理的, 経済的なる 球型が採用され，わが国に怙いても，東京を始め，大阪 名古屋など，主要都市においてはこの種都市ガス用高圧 ガス溜の建造が盛んに行なわれるにいたった。次に最近 然料界の留児といわれている石油精製時の副製物である ブタン, プロ ゚゚ンなどの夜化ガスの貯蔵器としてこの球 型タンクの要求が急激に上年しつつある。各種液化ガス の眝蔵器としての球型タンクは液体貯蔵器であると同時 に一種のガスホルダーでもある。この他石油化学または 化学肥料工業などにその需用は年とともに增加の一途を たどっている。以上のごとく高压ガス溜として球型タン クが圧倒的に数多く採用されるにいたったのはその型状 が最も合理的, かつ経済的であるという理由によること ああるが，これに使用される最も良質なる高張力鋼の出 現とこれを組み立てるに不可欠なる溶接技術の長足なる 進歩発展の賜であるといって過言でない。球型ガス溜は 貯蔵物の容量, 圧力に応じて設計された鋼板製球体にそ の負荷状態により設計された，数本もしくは十数本の脚 柱を取り付け，基碟上に設置されたるので構造は極めて 簡単，ただ前述のごとくその用材ならびに建設技術の传 秀性によってのみ安全を期し得る眝蔵器である。現在ガ ス溜としては $100,000 \mathrm{~m}^{3}$ (N.T.V.) まで建造されて いる。

\section{3. その他の貯棈}

以上の他詝槽としては石炭などの固形材，セメントな ど粉末材を貯蔵する，いわゆる各種サイロ，または朢型 貯槽に必要高度の支柱を設けた高架水槽などがあるが, いずれる前述の各種眝槽と適当なる鉄構造物とを組み合 わせ設計せられたすのでその種類は用途に応じ枚挙にい とまがない。

\section{4. 貯槽およびガスホルダーの今昔}

往時各種貯槽ならびにガスホルダーの建造はすへて鋼 材を鋲接合法により行なわれていたが, 球型ホルダーの 項で述べたことく近年, 特に日本においては戦後その主 要材料である鋼材の材質が著しく進歩改良され均質であ ることは勿論，強度の点加工性の点が戦前とは比較にな ら奴程の向上で一例を挙げれば, 原油 $10,000 \mathrm{k} l$ の眝槽 が戦前普通鋼板を使用し鉸鋲により組み立てた場合の総 重量は約 $400 \mathrm{t}$ であったるのが側板の一部を高張力鋼に 代え，全溶接構造により建造される現在ではその総重量 約 $300 \mathrm{t}, 25 \%$ の派減々なり溶接棒の改良も長足の進歩 を遂げその接合の効率す作業方法の発達拈よび事後の検 查方法の確立により往時の鋲接合に対し 20 30\% の上 
暴を見るにいたった。そのため眝槽ガスホルダーの建造 用鋼材の重量を著しく節減し得たと同時飞鋲接合と異り その漏洩に対する必配は皆無の状態となった。

\section{むす ひ}

近年あらゆる産業の進步発展にとすない，その製産工 場における原料るしくは製品の眝蔵設備は最る重大なる 使命をにな5一部であって，他の生産諸設備とともにそ の建設に当っては最も経済的かつ安全性を尊ぶはると ク，使用に当って最も能率的であるよう，これが建設業 界に拉いては日夜工夫, 改善が行なわれている。また各 種貯槽およびガスホルダーの規模においても，その事業 の発展または様式の変化にとるない暫次大型化しつつあ る現状で，かの精油所に括ける原油眝槽で 1 基 100,000 $\mathrm{k} l$ 以上のるのが計画されるごとき, その進歩, 発達は 意々期して俟つるのがある。

\section{計装*}

遠山武**

\section{1. 総 説}

工業プロセス計装に使用される工業計器（検出端, 测 定計器, 調節器) 操作部 (制御弁, 操作装直, 特殊ポン プなど）, 情報処理装膡（モニタ，ロガ，計算機など）， および計装附帯設備を総称して計装機器という。計装機 器の発達は戦前からあったが，現在の活況にいたる主要 なる発展は戦後で，特にプロセスの自動制御を含む本格。 的なプラント計装が普及したのは主として昭和 27 年以 降である。表 1 は昭和 25 年度を 100 として示した逐年 の工業計器生産指数であるが (生産動態統計), 近年に 指けるこの急激な增加の原因はつぎの3つの理由による ものである。

* 昭和 36 年 7 月 22 日受理

**（株)北辰雾機製作所

表 2 電気式統一信号計装方式工業計器

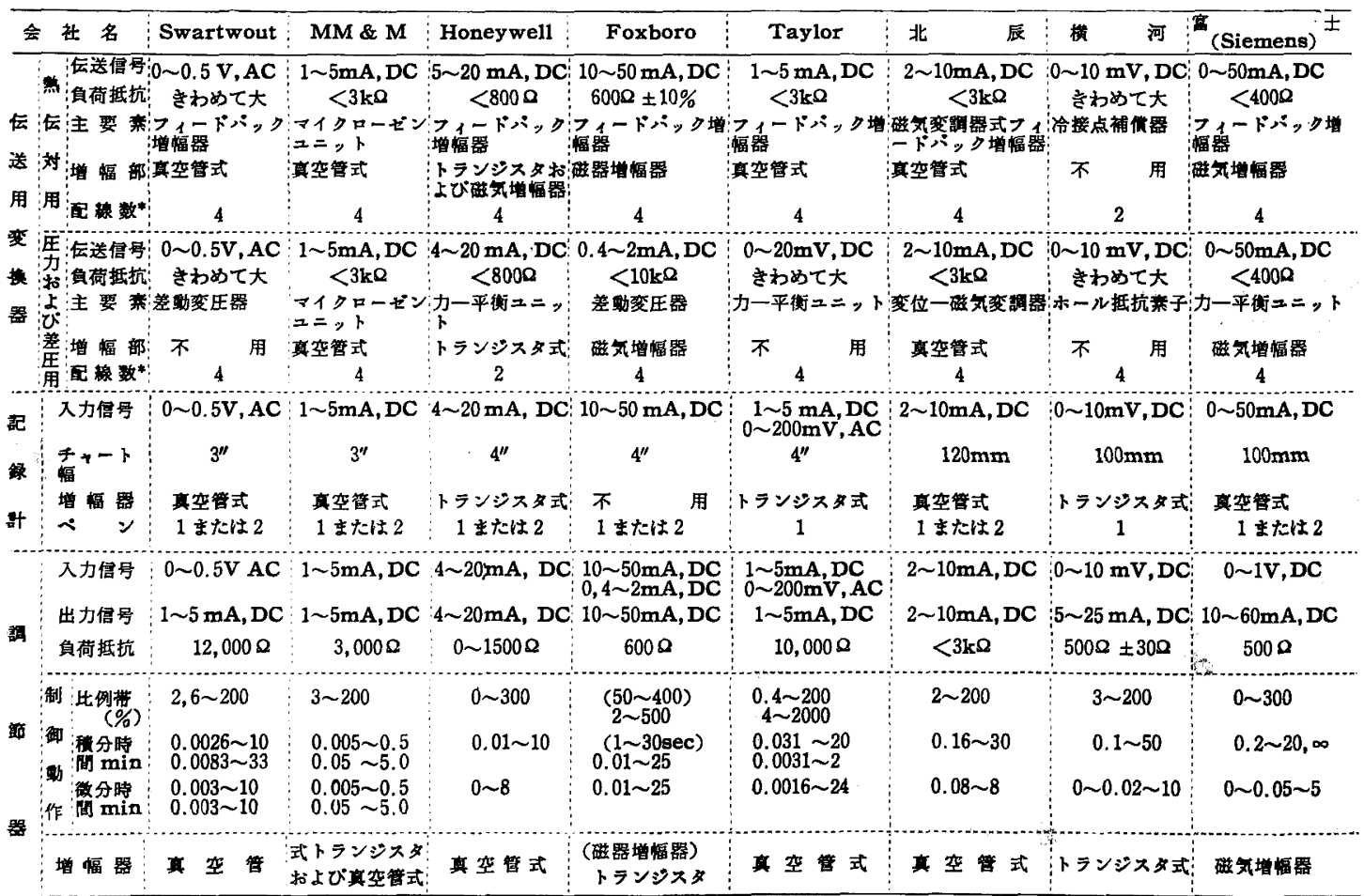

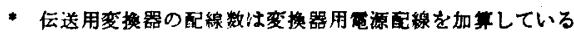


表 1 工業計器生産指数

\begin{tabular}{|c|c|c|c|}
\hline 年 度 & 指 数 & 年 度 & 指 数 \\
\hline 明和25 & 100 & 昭和30 & 481.5 \\
\hline 26 & 126.9 & 31 & 749.6 \\
\hline 27 & 182.5 & 32 & 1241.7 \\
\hline $28^{*}$ & 273.2 & 33 & 1143.0 \\
\hline 29 & 403.0 & 34 & 1592.3 \\
\hline
\end{tabular}

1）戦後技術導入によって建設されたプラントが高度 に計装されて掠り，その影響で計装が一般化したこと。

2) 国産計器の技術水準が急速に向上して, 従来輸入 計器に頼っていた分野も国産計器を使用するようになっ たこと。

3）プロセス，プラントの設備投資が逐年急增したこ

表 3 国内各社のデータ処理装置一覧表

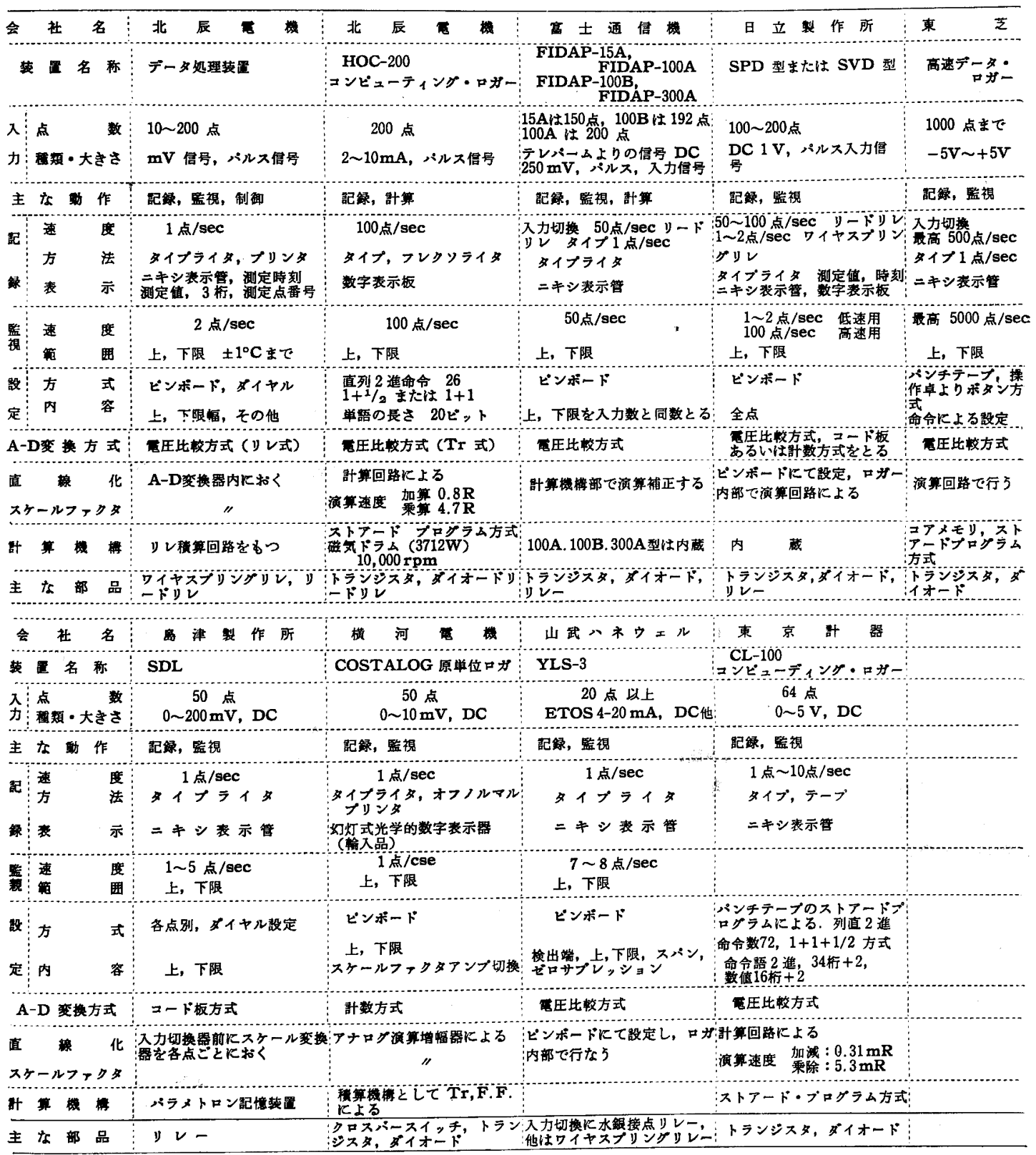


表 4 計装機器に関する主なる技術提捞

\begin{tabular}{|c|c|c|c|c|}
\hline 昭 & 会 & 程 & 提 㩲 技 術 項 目 & 搃 \\
\hline & 山武ハネウェル部器 （株） & 甲 & 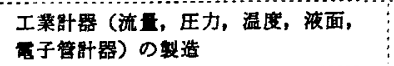 & $\begin{array}{l}\text { Minneapolis-Honeywell Regulator Co. } \\
\text { (米) }\end{array}$ \\
\hline & 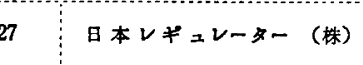 & 甲 & 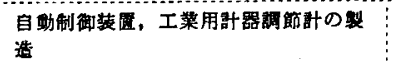 & Askania RegùlatorCo. (米) \\
\hline & 東 京 栰 器 工 莱 (株) & 甲 & アスカニヤ式制御装置および附属計矵器類 & Askania Werke A.G. (独) \\
\hline & （株）掼河雷機製作所 & 甲 & 機械式工莱郡器および制御䔩羁 & The Foxboro Co. (*) \\
\hline & (株) 北辰雪機彆 作所 & 甲 & 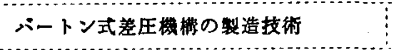 & Barton Instrument Corp. (米) \\
\hline & （株）北辰電機製作所 & 甲 & 工慗計罢の製造技街 & Fischer \& Porter Co. (*) \\
\hline & （株）東京訫器製造所 & 甲 & 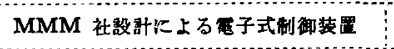 & The Manning Maxwell \& Moore Inc. (*) \\
\hline & （株）岛 津 製 作 所 & 甲 & 工桇㖕器の㱔造技術 & Taylor Instrument Co. (米) \\
\hline & 東 京 树 器 工莱 (株) & 甲 & 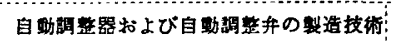 & Fisher Governor Co. (米) \\
\hline & (株) 北辰電機 製 作所 & 甲 & 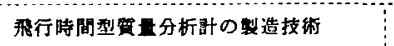 & Bendix Aviation Corp. (*) \\
\hline
\end{tabular}

以上の理由により計装機器の技術的発展も昭和 $26 \sim 28$ 年を境にして，それ以前と以後とでは，いちでるしい娊 隔がある。以下戦前から昭和 25 年頃までを前期, 昭和 26 年以降を後期と呼んで区別することにする。

\section{2. 工業計器の技術的発展}

前期では戦前から硫安工業, 石油精製工業などにおい て流量, 压力, 温度などの指示計, 記録計, 空気式調節 計扣よび油圧式調節器が使用されていた。計器の形状は 丸形が多く, 流量, 差瓦は水銀式（リング・バランス式 を含む)，层送はインダクション・バランス方式が普通 であった。压力計は計器にブルドン管（ヘリカル，スパ イラル)、ベローズなどを内蔵する方式。温度計は調節計 には膨張式, 記録計, 指示計飞は電気式可動線輪形が用 いられていた。機械式の自動平衡電位差計式計器も一部 国産化されて使用された。油圧式の調節器はドイッアス カニヤ会社の方式のものが専ら硫安, 石油, 各種然焼装 置などで用いられていた。

後期の発展の第 1 は電子管式自動平衡計器の国産化で ある。これは昭和 25 年〜昭和 28 年頃に各社で一斉に 発表され, その後の国産工業計器の主流となった。機械 式の自動平衡計器はこれによってまったく影をひそめた か，可動線輪式の指示計，記録計は安価なため引き続き 利用されている。しかしそれらの生産額の相対値は電子 管自動平衡計器に比してまったく小さなるのになった。

電子管自動平衡計器の発達によって各種のプロセス変 量の工業測定が実用化された。 $\mathrm{pH}$ 計はそのいちじるし い例である。

第 2 の発展は空気圧式調節計器のいちじるしい普及で ある。これは前期にも用いられたが，後期にいたって質 的にも量的にも飛睈的発展を遂げ, 特に前記電子管自動
平衡計器と組み合わせて広く用いられるようとなった。

第 3 の発展は統一信号方式の計器の発達である。これ はアメリカで 1949 (昭 24) 年頃から実用化された, い わゆる図示パネル計器で，すべてのプロセス変量を 3〜 $15 \mathrm{psi}\left(0.2 \sim 1.0 \mathrm{~kg} / \mathrm{cm}^{2}\right)$ の空気圧飞変换して, 指示, 記録および制御用の信号とするすのである。昭和29～30 年頃にはこれも国産化された。続いて 1955 年（昭 30 年）頃には電子式の統一信号方式がアメリカで開発さ れ，その後昭和 35 年前後から国産計器の花形商品にな ろうとしている。これら統一信号方式の計器の発達とと るに計器の小形化が一般化し, 多数の計器を取り付ける 計器パネルが従来の $1 / 8$ 程度ですむよ5になった。電子 式統一信号方式は表 2 に示すようなるのが現在開発され ているが，表に見るごとく各社毎に採用している統一信 号はまちまちで，これが近い将来に一本になる様子す見 えない。

\section{3. 操作部の進歩}

空気圧式調節器の発達とともに空気式ダイヤフラム升 が広く用いられ，多量に製造された。また空気式計装の 附帯設備として空気脱湿精製装固の需要が起り，専業製 造業者す数社を数えるにいたった。

油圧式操作部は油圧式調節器と一体となって, 油圧調 節器メーカによって製造された。

電子式統一信号方式では操作部に空気式または油圧式 を用いるすのが多く，そのため電気信号を空気圧信号ま たは油圧信号に変換する電-空変換器または電-油変換器 が必要となる。あるいは空気式また油圧式の操作部汇電 気信号によって動作するニニットをつけたるのが用いら れる。この5ち電一空変換器は工業計器メーカーによっ て製作されたが，油圧式との組み合わせは後者の方式が 
一般的である。電子式の普及とともに油圧調節器メーカ 一は将来主として電気一油圧式操作部を製造するメ一カ 一になるであろらと思われる。

\section{4. ブロセス用情報処理装置の進歩}

プロセス・モニタ, データ・ロガなどのプロセス用情 報処理装置が 1954 年（昭 29 年）頃からアメリカで使 用され始め、日本でる昭和 32 年頃か!ら製作が開始され た。これらはプロセス・プラント中の多数の点の測定値 の情報をつぎつぎと切り替え走查して，上下限設定値と 此較監視（モニタ）しあるいは（および）数字記録 （ロガ）するるのである。近年さらにそれに計算機能を 加えた：コンピューティング・ロガまたはプロセス制御 用計算機が製作され，使用されようとしている。初期の モニタおよびロガはすべて可動部分のあるリレーから構
成されていたが，近来のものは次第に固体電子部品によ って怙きかえられつつある。表 3 は昭 36 年 4 月現在に おけりる国産情報処理装置の概要を示したものである。

\section{5. 計装機器に関する技術提携}

計装機器産業も終戦後いちじるしい技術の立ち遅れに 対し，外国会社と技術提携することによって，技術の向 上を図った。表 4 は年代順にそれを表示したものであ る。これは直接計装機器に対する技術提擭であるか，そ の外飞電子機器, 通信機器, 電子応用装置, 半導体素子 などに関する他の分野の技術導入の成果も，国産計装機 器の急速な進歩に大きな寄与をしている。今日国内で開 発されつつある新しい電子式計装機器および情報処理装 置の多くの部分は直接の技術提携によらないで製作され つつあることを附記して本稿を終わる。

\section{発明より見た化学装是の進歩*}

田辺義 一***

化学工業の進歩発達は戦前に比較して戦後著しいこと は改めて申すまでもないが，その中です化学機械装置の 著しい進歩は警異すべき事柄である。このことは戦後に 輸入された機械器具が格段に改良されていることでる明 らかである。戦前に実施された工業に拉いても新しいア イディアによる操作を適用することによって全生産の合 理化に寄与していることは極めて周知のことであるばか クでなく，戦後の新しい化学工業に括いては事業の新規 なことの他にそれに使用されている操作はとくに優れた 化学機械装盾を使用して能率よく経済的なあり方で実施 されている。外国の技術導入により脚光を浴びている工 業は申寸まですない。

特許発明の方面からこれを観察してみると，戦後昭和 25〜26年頃より特許出願が増加の一途をたどり，とくに 外国よりの出願件数は逐次增加し，特許出願中の約 $30 \%$ 近くは外国人の出願となっている。化学工業方面に拉い ては有機合成化学, 高分子化学またこれらを応用した一 般の有機化学関係の出願は類別からみても毎年ペストテ ン第 1 位を維持し，如何に化学工業が最近工業界で飛躍 しているかがうかがえるのである。

*昭和 36 年 7 月 25 日变理

**特部宁
化学装置に関してもそれに漏れす戦後の発明には戦前 に見られなかった新しいアイディアのものが多く見られ るようになった。

今回は戦前の発明については簡単な説明を加え, 戦後 今日迄如何に変化してきたかを発明の方面から解説を加 えることにする。

\section{1. 流動 化反応}

従来は固体触媒を使用してガス化反応を行なわせる場 合には, 塔式の装置内に固体触媒を定置してガスを下方 より通ずる方式が普通に実施されていたが, ガス速度が 比較的遅く充埧した触媒が躍らない程度である。反応生 成物の量はガスの導入量と共に増大し, それにつれて温 度の上升が烈しくなるため, 反応層の能力は反応熱如何 に制限を受ける。今次大戦の初頭に石油, 軽燈油をアル ミナ系触媒を用いて分解し高オクタン価のガソリンを製 造するフードリー法も固定触媒で反応した後に触媒の酸 化再生が必要であったが，この式の方法を流動法で行な 5 研究を 1941 年に Standard Oil Co. とマサチウセッッ 工科大学などの協力を得てパイロットプラントが建設さ れ, 翌年には工業化に進展した。粉末物質反応に流動化 法を用いたものは別に新しいことでなく、Winkler 式の 